\title{
Comparative Waste Forms Study
}

\author{
J. W. Wald \\ R. O. Lokken \\ J. W. Shade \\ J. M. Rusin
}

December 1980

Prepared for the U.S. Department of Energy under Contract DE-AC06-76RLO 1830

Pacific Northwest Laboratory Operated for the U.S. Department of Energy by Battelle Memorial Institute 
NOTICE

This report was prepared as an account of work sponsored by the United States Government. Neither the United States nor the Department of Energy, nor any of their employees, nor any of their contractors, subcontractors, or their employees, makes any warranty, express or implied, or assumes any legal liability or responsibility for the accuracy, completeness or usefulness of any information, apparatus, product or process disclosed, or represents that its use would not infringe privately owned rights.

The views, opinions and conclusions contained in this report are those of the contractor and do not necessarily represent those of the United States Government or the United States Department of Energy.

PACIFIC NORTHWEST LABORATORY

operated by

BATTELLE

for the

UNITED STATES DEPARTMENT OF ENERGY

Under Contract DE-ACO6-76RLO 1830

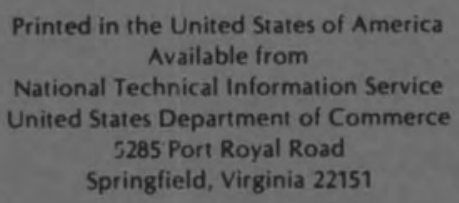

Price: Printed Copy $\mathbf{s}$

$\because$ Microfiche $\$ 3.00$

NTIS

-Pages Selling Price

$\begin{array}{ll}001-025 & \$ 4.00 \\ 026-050 & \$ 4.50 \\ 051-075 & \$ 5.25 \\ 076-100 & \$ 6.00 \\ 101-125 & \$ 6.50 \\ 126-150 & \$ 7.25 \\ 151-175 & \$ 8.00 \\ 176-200 & \$ 9.00 \\ 201-225 & \$ 9.25 \\ 226-250 & \$ 9.50 \\ 251-275 & \$ 10.75 \\ 276-300 & \$ 11.00\end{array}$


PNL -3516

UC -70

33679000553331

COMPARATIVE WASTE FORMS STUDY

J. W. Wald

R. 0. Lokken

J. W. Shade

J. M. Rusin

December 1980

Prepared for

the U.S. Department of Energy under Contract DE-AC06-76RLO 1830

Pacific Northwest Laboratory Richland, Washington 99352 


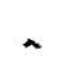




\section{SUMMARY}

A number of alternative process and waste form options exist for the immobilization of nuclear wastes. Although data exists on the characterization of these alternative waste forms, a straightforward comparison of product properties is difficult, due to the lack of standardized testing procedures. The characterization study described in this report involved the application of the same volatility, mechanical strength and leach tests to ten alternative waste forms, to assess product durability. Bulk property, phase analysis and microstructural examination of the simulated products, whose waste loading varied from $5 \%$ to $100 \%$ was also conducted. The specific waste forms investigated were as follows:

1) Cold Pressed and Sintered PW-9 Calcine

2) Hot Pressed PW-9 Calcine

3) Hot Isostatic Pressed PW-9 Calcine

4) Cold Pressed and Sintered SPC-5B Supercalcine

5) Hot Isostatic Pressed SPC-5B Supercalcine

6) Sintered PW-9 and 50\% Glass Frit

7) Glass 76-68

8) Celsian Glass Ceramic

9) Type II Portland Cement and 10\% PW-9 Calcine

10) Type II Portland Cement and 10\% SPC-5B Supercalcine

Bulk property data were used to calculate and compare the relative quantities of waste form volume produced at a spent fuel processing rate of 5 metric ton uranium/day. This quantity ranged from $3173 \mathrm{~L} /$ day $(5280 \mathrm{Kg} /$ day $)$ for $10 \% \mathrm{SPC}-5 \mathrm{~B}$ supercalcine in cement to $83 \mathrm{~L} /$ day $(294 \mathrm{Kg} /$ day) for $100 \%$ calcine. Mechanical strength, volatility, and leach resistance tests provide data related to waste form durability. Glass, glass-ceramic and supercalcine ranked high in waste form durability where as the $100 \% \mathrm{PW}-9$ calcine ranked low. All other materials ranked between these two groupings.

The data presented in this report will be beneficial in the comparison of waste forms. The final selection of promising waste form systems must take into consideration process complexity and feasibility as well as product volume and durability. 


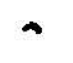

.

. 
SUMMARY

INTRODUCTION

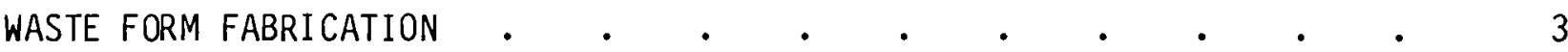

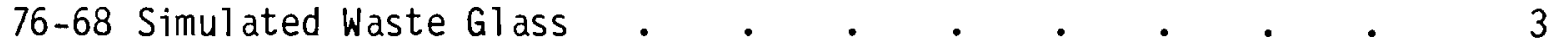

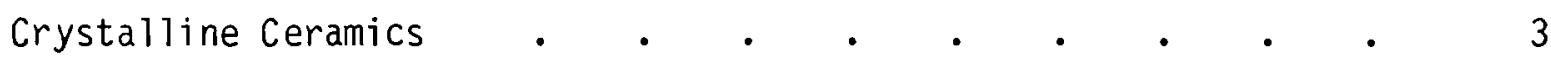

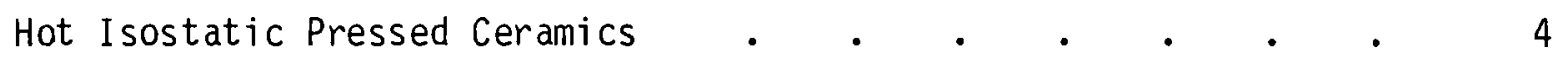

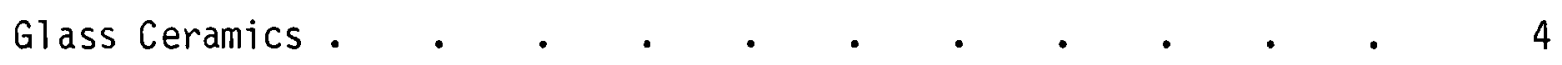

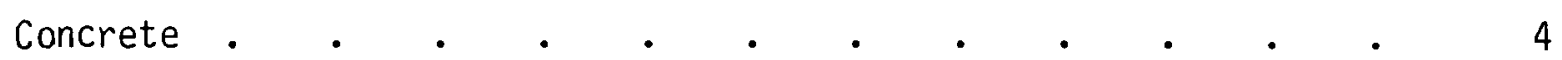

WASTE FORM CHARACTERIZATION

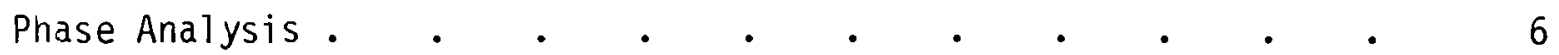

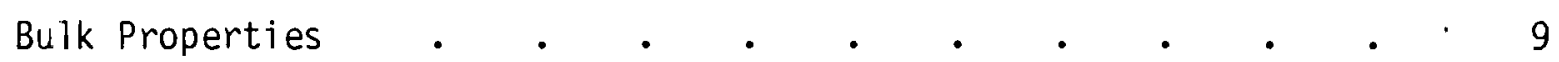

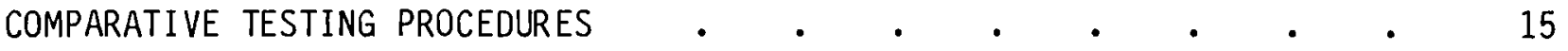

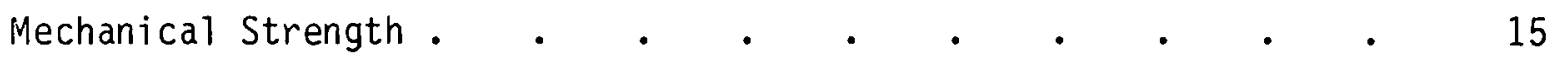

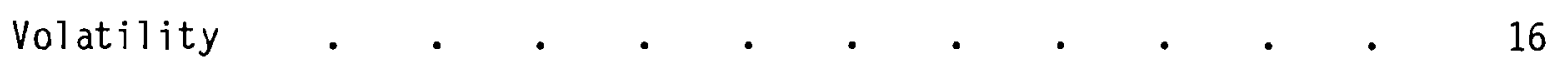

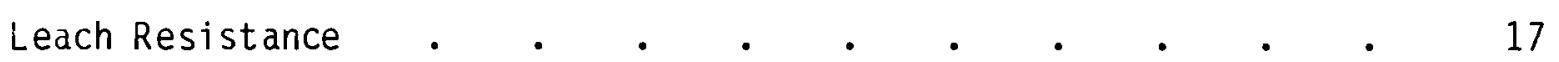

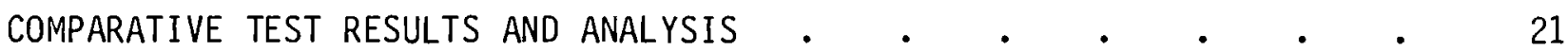

Mechanical Strength . $\quad$ • . . . . . . . . . . 21

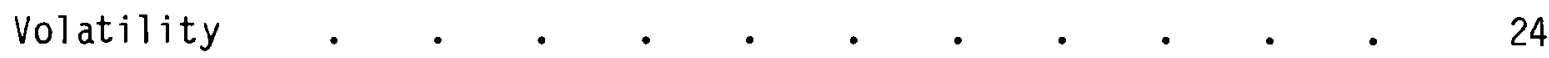

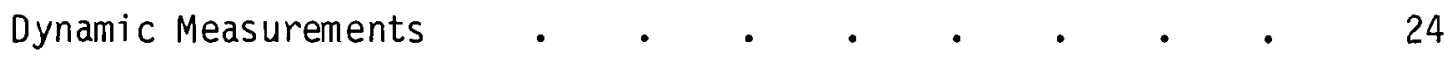

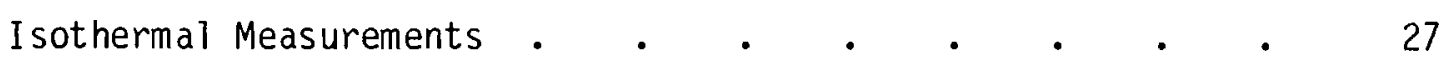

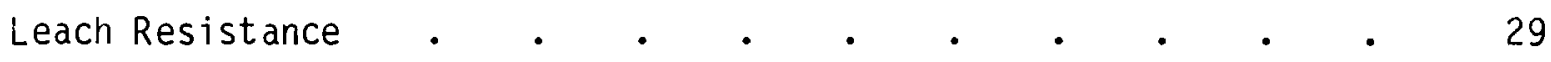

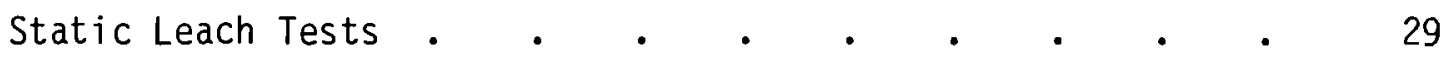

Effects of Time, Temperature, and SA/SV . . . . . 32 


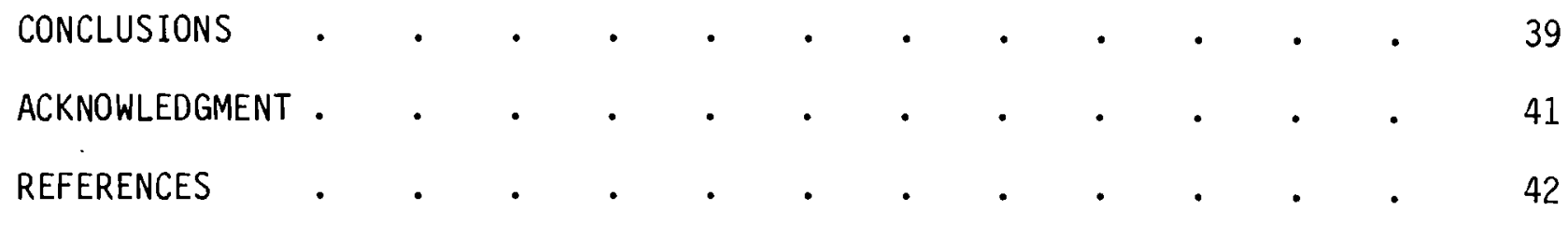




\section{FIGURES}

1 Microstructure of Glass-Based and Cement-Based Waste Forms . $\quad 10$

2 Microstructure of Crystalline-Ceramic Waste Forms . . . . . 11

3 Microstructure of Hot Isostatic Pressed Waste Forms . . . 12

4 Geometry of Box-Behnken Design for Three Variables . . . 18

5 Diametral Compression Test Results for Eight Ceramic and

Glass Alternative Waste Forms . . . . . . . . 22

6 Volatility During the Preparation of Various Alternative

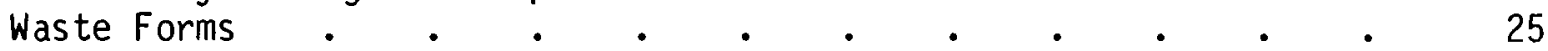

7 Isothermal Volatility Measurements Made on Fabricated

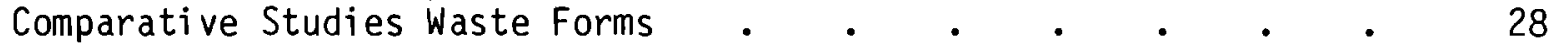

8 Effect of Time, Temperature, and SA/SV on Leach Resistance

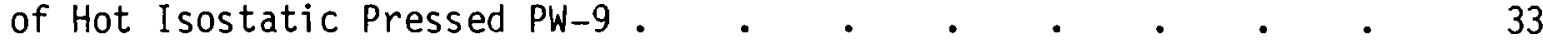

9 Effect of Time, Temperature, and SA/SV on Leach Resistance
of 76-68 Glass

10 Effect of Time, Temperature, and SA/SV on Leach Resistance

11 Effect of Time and SA/SV on $\mathrm{pH}$ of Leachate for Selected
Waste Forms 


\section{TABLES}

1 Oxide Composition of Comparative Studies Waste Forms . . . 7

2 Comparison of as Defined and Analyzed Composition of Comparative Studies Waste Forms . . . . . . . . 8

3 Crystalline Phases Observed in Comparative Studies Materials . 9

4 Comparison of Bulk Properties of Ten Waste Forms . . . . 13

5 Apparent Densities and Open Porosity Values of Comparative

Studies Waste Forms . . . . . . . . . . . 14

6 Time, Temperature and Surface Area to Solution Volume Ratio

Combinations Used in the Comparative Leach Resistance Evaluations 19

7 Estimated Total Porosity Values and Mechanical Strength Values for Eight Comparative Study Materials . . . . . . . 23

8 Average Fraction of Condensable and Non-Condensable Volatilies Released From Five Waste Forms During Processing . • • • • • 25

9 Relative Amounts of Condensable Volatile Species Measured in the Off-gas Collected from Comparative Study Materials . • . 26

10 Leach Resistance of Selected Alternative Waste Forms . . . 30

11 Comparison of Leach Resistance of PW-9 Waste Forms . . . 31

12 Comparison of Leach Resistance of SPC-5B Waste Forms . . . 32

13 Comparison of Glass, Glass Ceramic and Supercalcine Waste Forms . 40 


\section{INTRODUCTION}

A number of alternative process and waste form options exist for the immobilization of nuclear wastes. These options can be categorized into six groups (Rusin 1978) including the reference monolithic glass process: glass, sintered ceramics, glass ceramics, hot-pressed ceramics, hot isostatic pressed ceramics, and castable ceramics (cements). In addition to these major groupings, more detailed process options involving coatings and inert matrices also exist. Although extensive data is available on these generic alternatives, straightforward comparisons of waste form properties is difficult, due to lack of standardized testing procedures.

The characterization study described in this report, involved the application of identical volatility, mechanical strength and leach resistance tests to ten specific waste form types from the above generic catagories. Parallel studies have also been conducted elsewhere to assess process complexity (Treat, 1980, Johnson, 1980). Comparative studies of process and product nature will prove important in the final assessment and selection of waste forms for the national waste management effort.

The ten waste forms prepared for property comparisons incorporated simulated nuclear waste loadings from $5 \%$ to $100 \%$ depending upon the waste form option. Nine of the waste forms were tailored from a simulated PW-9 (Ross et al., 1978) high sodium calcine. The glass form, PNL 76-68, was prepared from a simulated PW-8a calcine (Ross et al., 1978), which had a higher sodium and iron content.

The sintered ceramic products were cold-pressed cylinders of powder which were subsequently fired in air for consolidation. These included PW-9 calcine, PW-9 calcine plus $50 \mathrm{wt} \%$ of a glass forming frit, ${ }^{(a)}$ and supercalcine SPC-5B (MCElroy et a1., 1979). Hot pressing was applied only to the PW-9 calcine while hot isostatically pressed samples of both PW-9 calcine and SPC-5B supercalcine were produced. Formulation of the glass ceramic was based upon a celsian type (Lutze et al., 1979), and was prepared containing $20 \mathrm{wt} \% \mathrm{PW}-9$ calcine.

(a) 0. H. Hommel Co., Code OHCO 3GF29E 
Two concrete products fabricated from Portland type II cement ${ }^{(a)}$ were evaluated. One contained 10 wt\% PW-9 calcine the other 10 wt\% crystallized SPC-5B supercalcine.

(a) Lehigh Portland Cement Co., Type II, ASTM C-150 
WASTE FORM FABR ICATION

The fabrication processes employed in the production of samples for comparative testing a encompassed temperature span of from room temperature to $1200^{\circ} \mathrm{C}$, including procedures from cementation, cold pressing and sintering, and glass melting through hot-isostatic-pressing. It was not the intent in the fabrication to investigate processing parameters but rather to apply established procedures to existing simulated waste form materials. In most cases the overall waste form was designed specifically for a simulated calcine waste stream. The only exception in the materials studied was the celsian glass ceramic, which was designed for a lower sodium content calcine than the one used. The specific details of the development of processing conditions for the materials studied have been reported in numerous other publications, so only the specific fabrication details are given here.

76-68 Simulated Waste Glass

Glass containing 76-101 frit and PW-8a-4 calcine (2:1 by weight) was melted at $1200^{\circ} \mathrm{C}$ for 2 hours in a platinum cricible and cast into graphite molds which were preheated to $500^{\circ} \mathrm{C}$. The glass was air cooling to $\sim 500^{\circ} \mathrm{C}$ and annealed for one hour followed by a slow cool to room temperature. Samples were core drilled from the glass for characterization and testing. Crystalline Ceramics

Spray-calcined PW-9 powder was pressed into green compact cylinders at $7800 \mathrm{psi}$ in a $1.5 \mathrm{~cm}$ diameter hardened steel die. Butyl stearate was used as a die lubricant. The green pellets were sintered in air at $975^{\circ} \mathrm{C}$ for 2 hours with a heating and cooling rate of $200^{\circ} \mathrm{C}$ per hour. Frit/PW-9 calcine pellets (1:1 mixture) were prepared as above by pressing powder at 9200 psi and sintering for 2 hours at $750^{\circ} \mathrm{C}$. SPC-5B supercalcine pellets were pressed at 19,500 psi from powder which had been ball milled for 16 hours. The pellets were sintered at $1125^{\circ} \mathrm{C}$ for 2 hours with the same heating and cooling rates as above. 
Hot-pressed PW-9 calcine pellets were prepared by cold-pressing as-calcined powder in graphite dies at $1500 \mathrm{psi}$. The samples and dies were outgassed under vacuum for 45 minutes at $350^{\circ} \mathrm{C}$, and then hot pressed at 3500 psi for 20 minutes at $900^{\circ} \mathrm{C}$.

\section{Hot Isostatic Pressed Ceramics}

Samples of PW-9 calcine and SPC-5B supercalcine powders were prepared for consolidation by hot isostatic pressing (HIP) by heating as-calcined powders to $650^{\circ} \mathrm{C}$ for 4 hours to remove any water and residual nitrates. The powders were uniaxially pressed into a $5.4 \mathrm{~cm}$ diameter stainless steel cans at a pressure of 18,000 psi. A mild steel disk $6.4 \mathrm{~mm}$ thick was placed on top of the compacted powder, and a lid containing a filtered vacuum stem was welded to the can. The assemblies were evacuated, heated to $150^{\circ} \mathrm{C}$, sealed, and hot isostatically pressed. The PW-9 calcine sample was pressurized at room temperature in the HIP vessel by argon gas to $10,300 \mathrm{psi}$. The temperature and pressure were simultaneously increased to $890^{\circ} \mathrm{C}$, and $21,300 \mathrm{psi}$ respectively. The sample was held at $900^{\circ} \mathrm{C}$ and 21,300 psi for 2 hours, cooled to $390^{\circ} \mathrm{C}$, and depressurized. During the HIP cycle, the can developed slight bulges on the ends due to a probable leak in a weld resulting in internal pressurization and a pressure gradient during depressurization. The SPC-5B supercalcine sample was processed similar to $\mathrm{PW}-9$ except the sample was maintained at $1,000^{\circ} \mathrm{C}$ and 20,300 psi for 2 hours.

\section{Glass Ceramics}

Celsian glass ceramic was prepared by mixing 20 wt\% PW-9 calcine with glass frit and melting at $1200^{\circ} \mathrm{C}$ for 2 hours. The glass was cast into preheated graphite molds, allowed to air cool to $\sim 550^{\circ} \mathrm{C}$ and annealed for one hour and furnace cooled to room temperature. Crystallization was effected by heat treatment at $600^{\circ} \mathrm{C}$ for 3 hours to precipitate nucleation centers followed by $800^{\circ} \mathrm{C}$ for 12 hours for crystal growth. Heating and cooling rates were $2^{\circ} \mathrm{C} / \mathrm{min}$.

\section{Concrete}

Concrete waste forms were prepared by mixing type II Portland cement with 10 wt\% PW-9 calcine powder and enough water to form a smooth consistency paste 
(water/solid ratio was 0.34 to 0.37 ). The paste was cast into a mold, vibrated to releast entrapped air, sealed, and cured. As-calcined SPC-5B supercalcine requires heat treatment to form the desired crystalline phases; therefore, the powder was heated in air at $1125^{\circ} \mathrm{C}$ for 2 hours, ballmilled for 20 hours and screened to -100 mesh. The resultant powder was mixed with type II Portland cement and prepared as above. 
WASTE FORM CHARACTERIZATION

Characterization of the waste form types incorporated within this study was performed to provide not only physical/chemical data on each waste form but also to verify that suitable materials had been produced. Chemical analyses of both starting materials and fabricated waste forms were performed by Induction Coupled Plasma Spectroscopy (ICP), while X-ray diffraction and scanning electron microscopy were used for crystalline phase identification. Standard metallographic examination provided physical comparisons of the waste forms along with the density and porosity determinations made using a fluid immersion technique.

Phase Analysis

The as-defined oxide compositions of the waste products are given in Table 1. Actual composition as analyzed for selected elements of the waste forms is compared to the as defined composition in Table 2. The crystalline phases in the samples as determined by powder $x$-ray diffraction are identified in Table 3. Simulated 76-68 waste glass appears to be essentially vitreous except for some undissolved $\mathrm{RuO}_{2}$. The sintered $\mathrm{PW}-9$ calcine product contains a number of crystalline phases with the water soluble $\mathrm{Na}_{2} \mathrm{MoO}_{4}$ phase the most significant. The addition of glass frit altered this system to some extent with the elimination of some crystalline species at the expense of formation of others, namely $\mathrm{BaMoO}_{4}$. Sintered SPC-5B supercalcine has the most complex crystal chemistry of the waste form analyzed. The formation of pollucite, apatite, and fluorite phases are observed; however, it appears that complete reaction of nepheline and sheelite to form the sodalite solid solution has not occurred. Unreacted nepheline $\left[(\mathrm{Na}, \mathrm{K}) \mathrm{AlSiO}_{4}\right]$ is seen to exist along with a sodalite type analog Hauynite $\left[(\mathrm{Ca}, \mathrm{Sr}, \mathrm{Ba})_{2}\left(\mathrm{NaAlSiO}_{4}\right)_{6}\left(\mathrm{MoO}_{4}\right)_{2}\right]$. The Hauynite phase contains less of the nepheline phase than would be expected in the sodalite solid solution phase. Three major crystalline phases were present in the celsian glass ceramic product, and include a celsian phase $\left(\mathrm{BaAl}_{2} \mathrm{Si}_{2} \mathrm{O}_{8}\right)$, $\mathrm{BaMoO}_{4}$, and a rare- earth titanate $\left(\mathrm{RE}_{2} \mathrm{Ti}_{2} \mathrm{O}_{7}\right)$. Both cement waste forms were characteristic of the cement matrix materials rather than the waste constituents. The most abundant crystalline phases were calcium hydroxide and calcium silicate. 
TABLE 1. Oxide Composition of Comparative Studies Waste Forms

\begin{tabular}{|c|c|c|c|c|c|c|c|}
\hline Oxide & $\begin{array}{c}\text { PW-9 } \\
\text { Calcine }\end{array}$ & $\begin{array}{l}\text { SPC-5B } \\
\text { Super } \\
\text { Calcine }\end{array}$ & $\begin{array}{c}50 \% \text { PW-9 } \\
\text { Calcine } \\
50 \% \text { OHH } \\
36 F 29 E \text { FRIT }\end{array}$ & $\begin{array}{c}76-68 \\
\text { Waste Glass } \\
\text { PW-8a-4 Calcine; } \\
76-101 \text { FRIT }\end{array}$ & $\begin{array}{c}\text { Celsian } \\
\text { Glass Ceramic } \\
20 \% \text { PW-9 } \\
\text { Calcine }\end{array}$ & $\begin{array}{c}\text { Type I I } \\
\text { Portland Cernent } \\
10 \% \text { PW-9 } \\
\text { Calcine } \\
\end{array}$ & $\begin{array}{c}\text { Type I I } \\
\text { Port land Cement } \\
10 \% \text { SPC-5B } \\
\text { Supercalcine }\end{array}$ \\
\hline $\mathrm{Na}_{2} \mathrm{O}$ & 11.49 & 7.20 & 6.47 & 12.80 & 3.90 & 1.15 & 0.72 \\
\hline $\mathrm{Cr}_{2} \mathrm{O}_{3}$ & 0.68 & 0.42 & 0.34 & 0.44 & 0.14 & 0.07 & 0.04 \\
\hline $\mathrm{P}_{2} \mathrm{O}_{5}$ & 1.32 & 0.80 & 0.66 & 0.51 & 0.26 & 0.13 & 0.08 \\
\hline Sro & 2.39 & 0.75 & 2.06 & 0.40 & 0.48 & 0.24 & 0.08 \\
\hline $\mathrm{ZrO}_{2}$ & $1 \cup .99$ & 3.44 & 5.49 & 1.88 & 3.00 & 1.10 & 0.34 \\
\hline $\mathrm{Ag}_{2} \mathrm{O}$ & 0.17 & 0.11 & 0.03 & 0.03 & 0.03 & 0.02 & 0.01 \\
\hline $\operatorname{coO}$ & 0.29 & 0.09 & 0.14 & 0.04 & 0.06 & 0.03 & 0.01 \\
\hline $\mathrm{TeO}_{2}$ & 1.66 & 0.52 & 0.38 & 0.28 & 0.33 & 0.17 & 0.05 \\
\hline $\mathrm{BaO}$ & 3.76 & 1.18 & 7.57 & 0.59 & 15.64 & 0.38 & 0.12 \\
\hline NiO & 0.28 & 0.09 & 0.14 & 0.21 & 0.06 & 0.03 & 0.01 \\
\hline $\mathrm{Fe}_{2} \mathrm{O}_{3}$ & 2.97 & 1.86 & 1.48 & 10.34 & 0.59 & 4.15 & 3.86 \\
\hline $\mathrm{Rb}_{2} \mathrm{O}$ & 0.83 & 0.52 & 0.41 & 0.13 & 0.17 & 0.08 & 0.05 \\
\hline $\mathrm{Cs}_{2} \mathrm{O}$ & 6.60 & 4.13 & 3.30 & 1.09 & 1.32 & 0.66 & 0.41 \\
\hline $\mathrm{MoO}_{3}$ & 11.77 & 3.69 & 5.88 & 2.42 & 2.36 & 1.18 & 0.37 \\
\hline $\mathrm{CeO}_{2}$ & 7.93 & 2.48 & 3.96 & 1.26 & 1.59 & 0.79 & 0.25 \\
\hline${ }_{2}{ }_{2} O_{3}$ & 0.67 & 0.42 & 0.33 & 0.23 & 0.13 & 0.07 & 0.04 \\
\hline $\mathrm{La}_{2} \mathrm{O}_{3}$ & 10.53 & 6.60 & 5.26 & 0.56 & 2.11 & 1.05 & 0.66 \\
\hline $\operatorname{Pr}_{0} O_{11}$ & 2.53 & 4.76 & 1.26 & 0.56 & 0.51 & 0.25 & 0.48 \\
\hline $\mathrm{Nd}_{2} \mathrm{O}_{3}$ & 3.38 & 5.25 & 4.19 & 4.67 & 1.68 & 0.84 & 0.53 \\
\hline $\mathrm{Sim}_{2} \mathrm{O}_{3}$ & 1.43 & 0.89 & 0.71 & 0.35 & 0.29 & 0.14 & 0.09 \\
\hline $\mathrm{Gd}_{2} \mathrm{O}_{3}$ & 1.08 & 0.68 & 0.54 & 0.05 & 0.22 & 0.11 & 0.07 \\
\hline $\mathrm{Rh}_{2} \mathrm{O}_{3}$ & 1.04 & 0.65 & 0.52 & 0.18 & 0.21 & 0.10 & 0.07 \\
\hline PdO & 3.91 & 1.23 & 1.95 & 0.56 & 0.78 & 0.39 & 0.12 \\
\hline $\mathrm{RuO}_{2}$ & 7.32 & 2.29 & 3.66 & 1.13 & 1.47 & 0.73 & 0.23 \\
\hline $\mathrm{CaO}$ & -- & 2.02 & 3.78 & 2.00 & 4.00 & 59.25 & 59.45 \\
\hline $\mathrm{Al}_{2} \mathrm{O}_{3}$ & -- & 27.26 & 3.54 & -- & 12.89 & 3.67 & 6.40 \\
\hline $\mathrm{SiO}_{2}$ & -- & 20.67 & 28.64 & 3.980 & 23.18 & 21.54 & 23.60 \\
\hline $\mathrm{B}_{2} \mathrm{O}_{3}$ & - & -- & 4.51 & 9.47 & 6.40 & -- & -- \\
\hline $\mathrm{TiO}_{2}$ & -- & $\cdots$ & - & 2.97 & 4.00 & -- & -- \\
\hline Nno & -. & -- & -- & 4.97 & 3.60 & -- & -- \\
\hline $\mathrm{k}_{2} \mathrm{O}$ & -- & -- & 1.48 & -- & -- & - & -- \\
\hline $\mathrm{Li}_{2} \mathrm{O}$ & -- & - & 0.49 & -- & 2.40 & -- & -- \\
\hline $\mathrm{MgO}$ & -. & - & 0.27 & -- & 1.20 & 1.69 & 1.69 \\
\hline $\begin{array}{l}\text { Waste } \\
\text { Loading }\end{array}$ & $100 \%$ & $50 \%$ & $50 \%$ & $33 \%$ & $20 \%$ & $10 \%$ & $5 \%$ \\
\hline
\end{tabular}


TABLE 2. Comparison of as Defined and Analyzed Composition of Comparative Studies Waste Forms

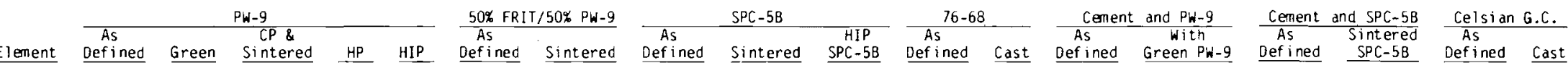

$\begin{array}{lccccc}- & 0.02 & 0.03 & 0.03 & 0.04 & 1.40 \\ 8.52 & \text { NA } & 11.00 & 7.71 & \text { NA } & 4.80 \\ - & 0.43 & 0.03 & 0.10 & 0.49 & 1.87 \\ - & 0.24 & 0.17 & 0.21 & 0.37 & 13.39 \\ - & 0.52 & 0.31 & 0.29 & 0.54 & 2.70 \\ 2.02 & 2.52 & 2.69 & 2.44 & 2.22 & 1.74 \\ 7.84 & 10.86 & 10.4 & 8.47 & 9.52 & 3.92 \\ 6.23 & 5.46 & 9.6 & 8.50 & 6.15 & 3.1\end{array}$

1.74
6.74
2.21
14.4
3.11
2.43
5.19
6.1

$-$

0.005

0.0

\begin{tabular}{ll}
$2.94 \quad 3.37$ \\
\hline
\end{tabular}

- $\quad 0.06$

5.34

7.56

$\begin{array}{rrrr}9.50 & 8.97 & 0.85 & 1.76\end{array}$

.

0.23

$1.99 \quad 4.03$

$14.43 \quad 12.6$

$9.6 \quad 15.1$

$1.44 \quad 2.54$

$\begin{array}{lllr}15.4 & 18.60 & 19.3 & 10.07\end{array}$

1.76
1.37

$\begin{array}{llll}0.53 & 1.33 & 2.89 & 3.02\end{array}$

$\begin{array}{llllll}2.54 & 2.65 & 1.43 & 1.62 & 42.35 & 31.64\end{array}$

$\begin{array}{llllllll}2.46 & 3.06 & 3.50 & 1.61 & 1.31 & 0.44 & 1.10 \\ 3.90 & 5.5 & 6.15 & 1.03 & 1.54 & 0.62 & 0.96\end{array}$

$\begin{array}{llll}3.39 & 1.54 & 6.83 & 6.20\end{array}$

$\begin{array}{llll}11.03 & 8.54 & 13.17 & 13.8\end{array}$

$\begin{array}{llll}42.49 & 31.90 & 2.86 & 3.06\end{array}$

$\begin{array}{llll}0.07 & 0.30 & 0.41 & 0.50\end{array}$

$\begin{array}{llll}0.25 & 0.53 & 1.57 & 1.83\end{array}$ 
TABLE 3. Crystalline Phases Observed in Comparative Studies Materials Waste Form Phase Observed

PW-9 (Sintered, $H P$, and HIP)

$\mathrm{CeO}_{2}$

$(\mathrm{Zr}, \mathrm{Ce}, \ldots) \mathrm{O}_{2}$

$\mathrm{Na}_{2} \mathrm{MoO}_{4}$

$\mathrm{RuO}_{2}$

SPC-5B (Sintered and $\mathrm{HIP}$ )

$(\mathrm{Ca}, \mathrm{Sr}, \mathrm{Ba})_{2}\left(\mathrm{NaAlSiO}_{4}\right)_{6}\left(\mathrm{MoO}_{4}\right)_{2}$

$(\mathrm{Na}, \mathrm{K}) \mathrm{AlSiO}_{4}$

$(\mathrm{Cs}, \mathrm{Na}) \mathrm{AlSi}_{2} \mathrm{O}_{6}$

$\mathrm{RuO}_{2}$

(Ce, $\mathrm{Zr}, \ldots) \mathrm{O}_{2}$

$\mathrm{Ca}_{2}(\mathrm{RE})_{8}\left(\mathrm{SiO}_{4}\right)_{6} \mathrm{O}_{2}$

$\mathrm{PW}-9+50 \%$ frit

$\mathrm{BaMoO}_{4}$

$\mathrm{RuO}_{2}$

(Unknown)

Glass $76-68$

$\mathrm{RuO}_{2}$

$\mathrm{Pd}$

Celsian Glass Ceramic

$\mathrm{BaAl}_{2} \mathrm{Si}_{2} \mathrm{O}_{8}$

$\mathrm{BaMoO}_{4}$

$\mathrm{RE}_{2} \mathrm{Ti}_{2} \mathrm{O}_{7}$

Cement $+\mathrm{PW}-9$

$\mathrm{Ca}(\mathrm{OH})_{7}$

+ SPC $-5 B$

$\mathrm{Ca}_{3} \mathrm{SiO}_{5}$

\section{Bulk Properties}

Figures 1 through 3 show typical micrographs of the ten comparative studies waste forms. The bulk density, determined by geometric measurements, ranged from $1.7 \mathrm{~g} / \mathrm{cm}^{3}$ for type II Portland cement plus PW-9 calcine to $3.5 \mathrm{~g} / \mathrm{cm}^{3}$ for 


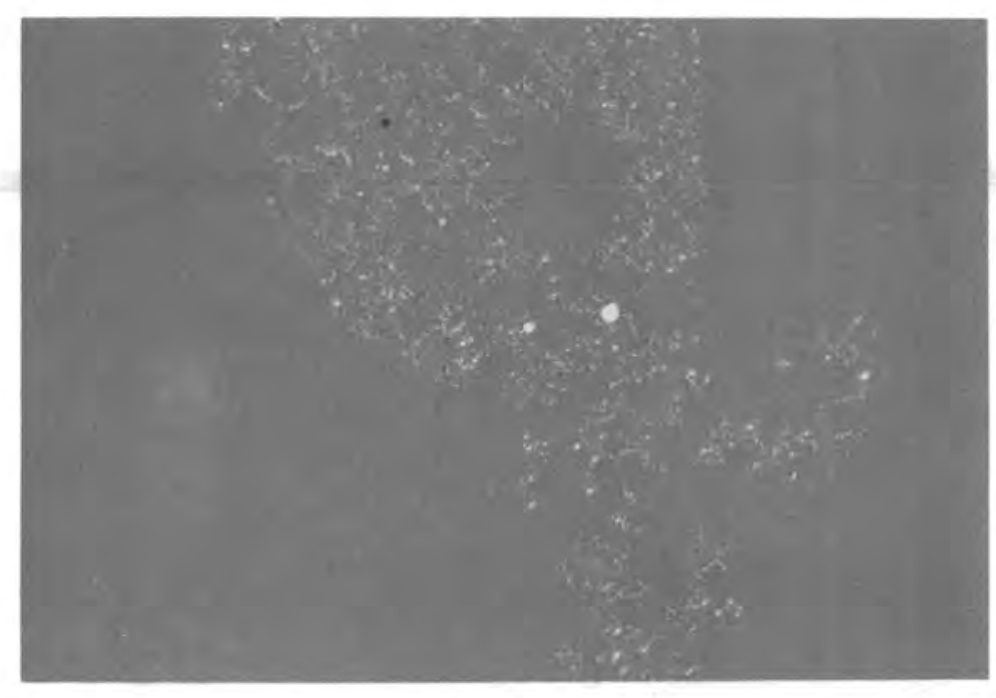

GLASS $76-68$

'。

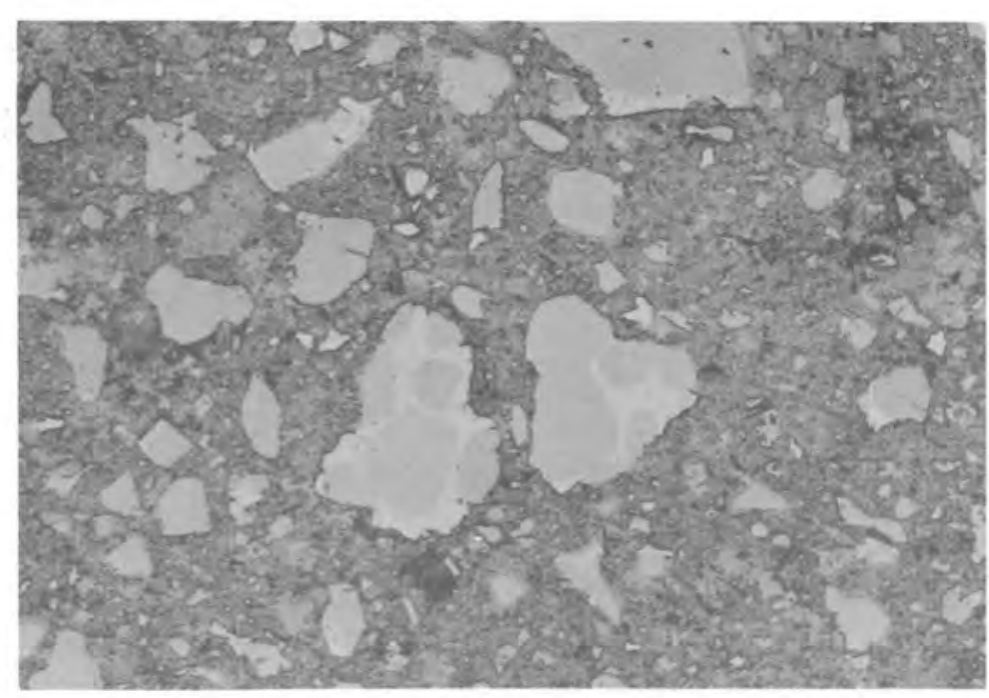

TYPE II CEMENT + 10\% PW- 9

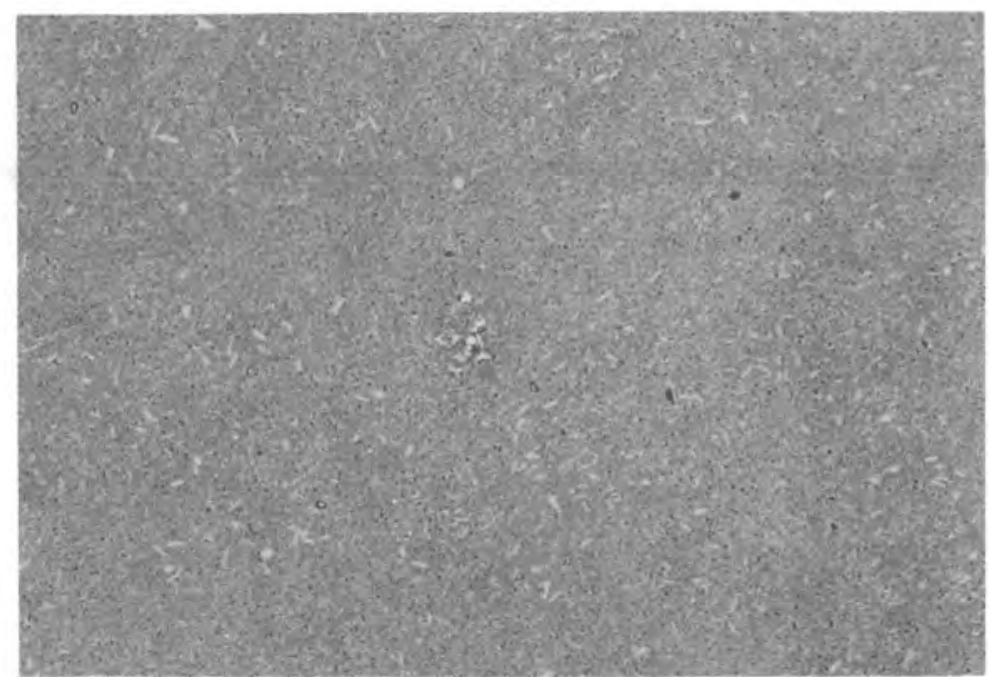

CELSIAN GLASS CERAMIC

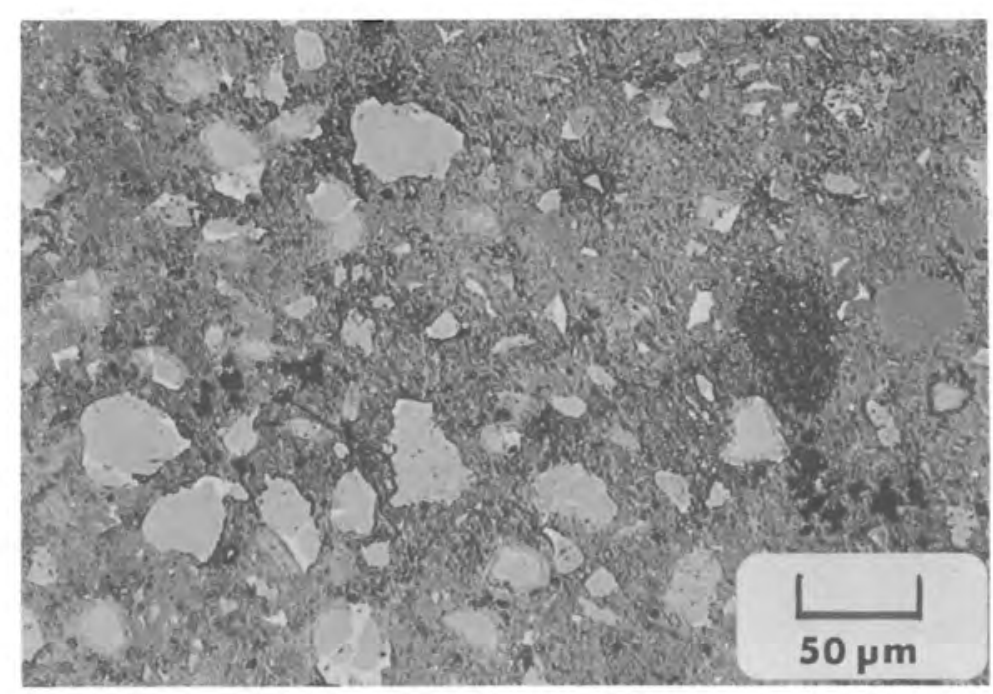

TYPE II CEMENT + 10\% SPC-5B

FIGURE 1. Microstructure of Glass-Based and Cement-Based Waste Forms. 


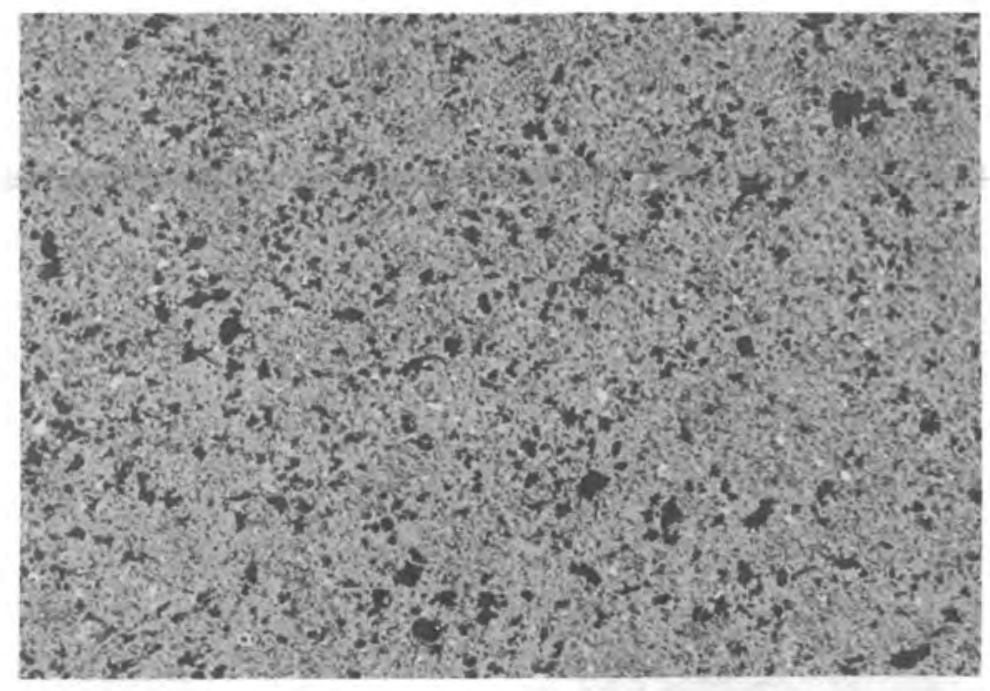

SUPERCALCINE SPC-5B SINTERED CERAMIC

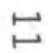

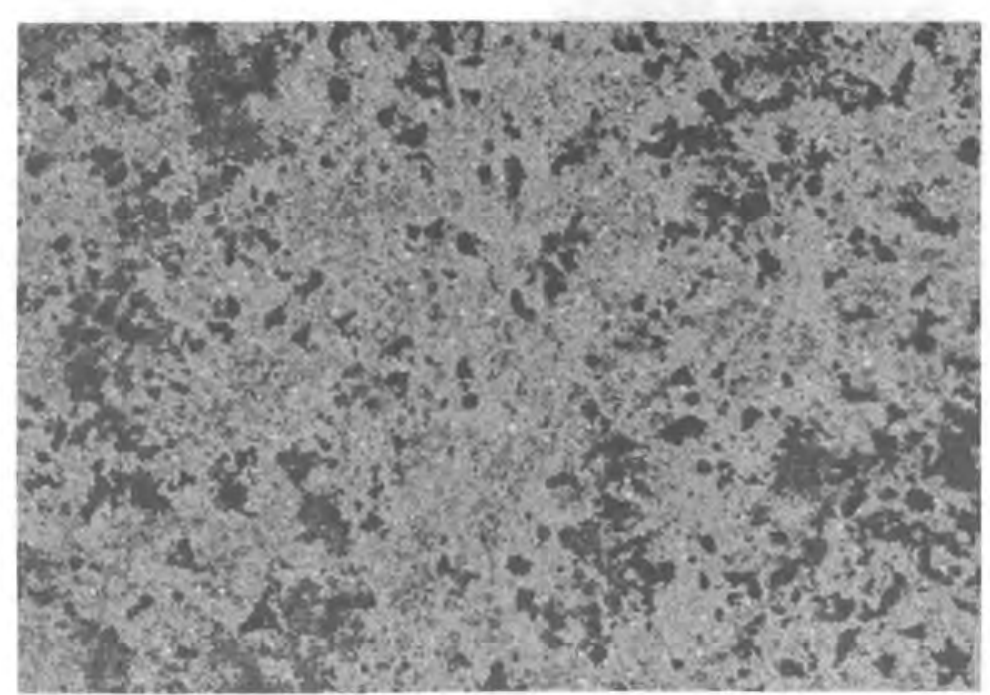

PW-9 SINTERED CERAMIC

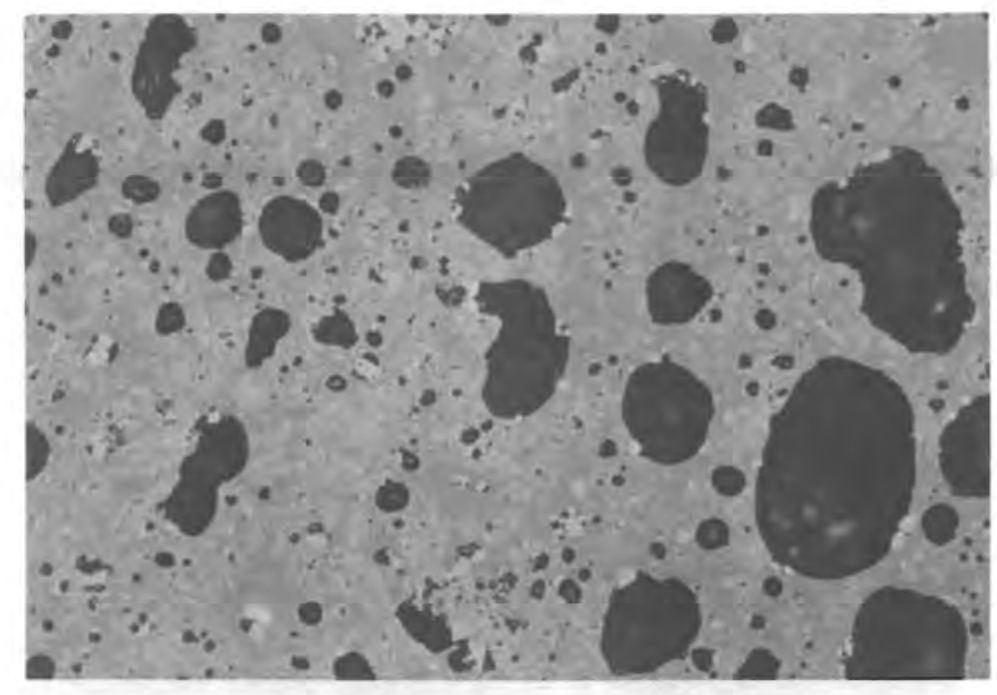

PW-9 \& 50\% FRIT SINTERED CERAMIC

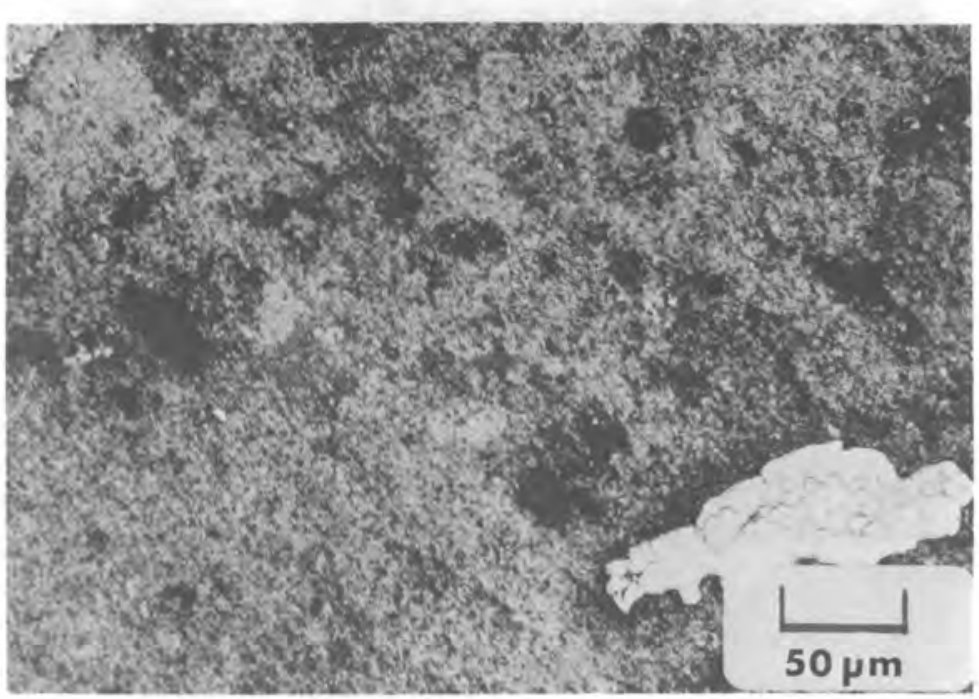

HOT PRESSED PW-9

FIGURE 2. Microstructure of Sintered-Ceramic Waste Forms. 


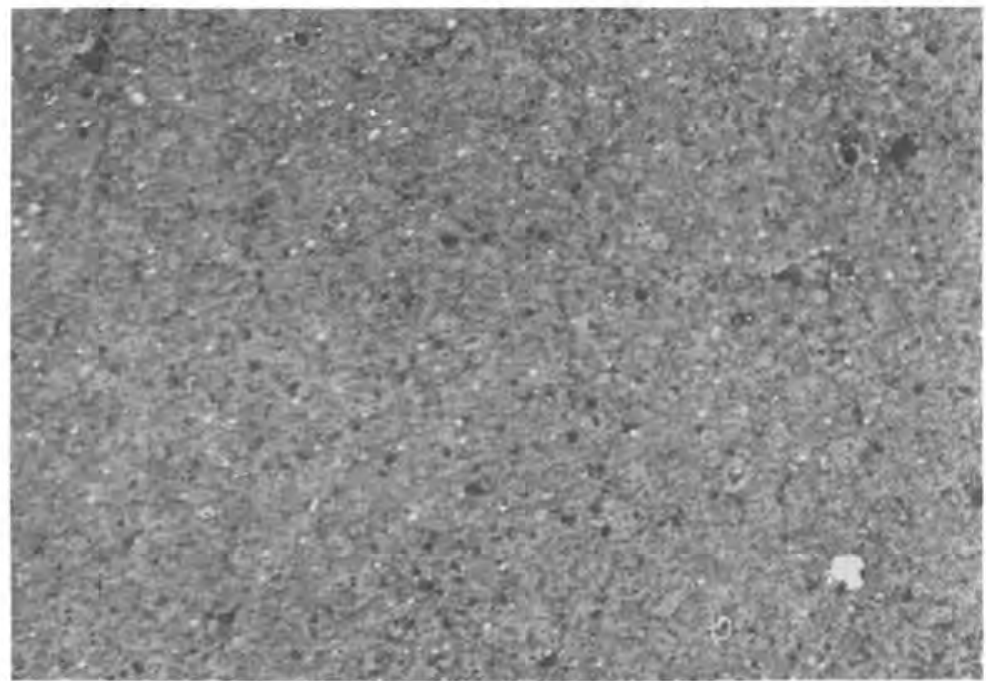

SUPERCALCINE SPC-5B

HOT ISOSTATIC PRESSED

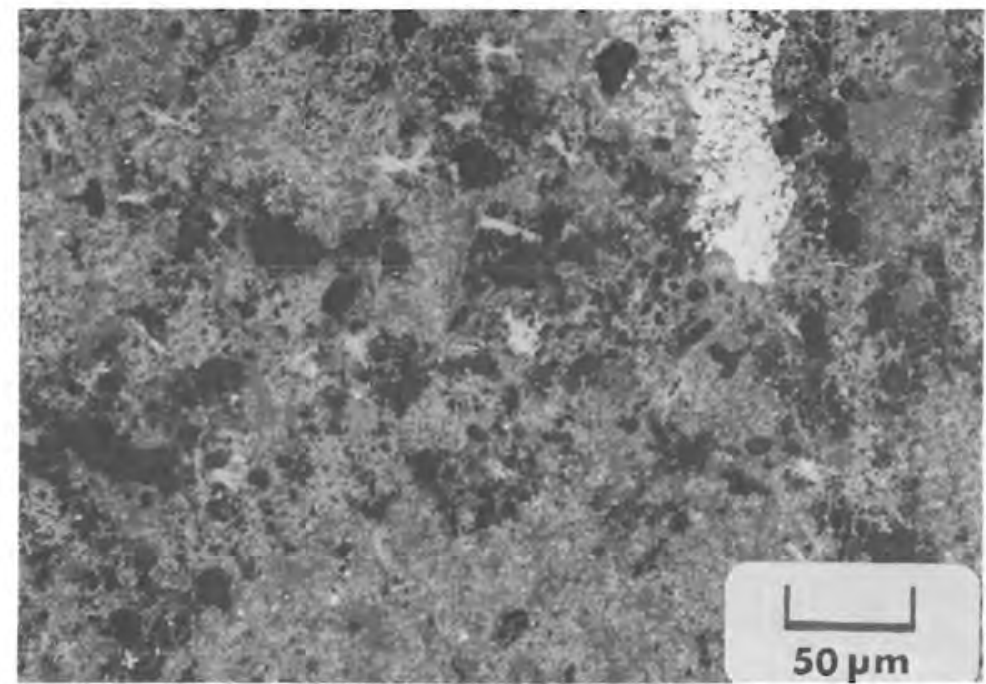

$\mathrm{PW}-9$

HOT ISOSTATIC PRESSED

FIGURE 3. Microstructure of Hot Isostatic Pressed Waste Forms. 
hot-pressed PW-9 calcine. A more important property, however, of the radioactive waste form is the product volume and weight required to solidify a given amount of high-level liquid waste. This property, termed waste density, is determined from the bulk density of the waste form and the waste loading. Table 4 lists the total product volume and weight required to solidify 5 MTU per day along with bulk density and waste loading for each waste form. It is assumed that $59 \mathrm{~kg}$ of solid waste is produced per metric ton uranium equivalent.

Apparent density and open porosity measurements were conducted on the ceramic samples and the results are shown in Table 5. Because of the reactions of some products in water, isopropyl alcohol was used as the immersion medium. The samples were first weighed dry, and then immersed in alcohol and evacuated for 20 minutes. A suspended weight is taken next, while the sample is held in the fluid, followed by a saturated weight after removal from the fluid. The saturated weight is obtained by rolling the specimen lightly on a wet cloth, which has been previously saturated with liquid. The sample is then weighed immediately to eliminate evaporation losses.

TABLE 4. Comparison of Bulk Properties of Ten Waste Forms

\begin{tabular}{|c|c|c|c|c|c|}
\hline Waste Product & $\begin{array}{l}\text { Waste } \\
\text { Loading } \\
\text { (wt\%) } \\
\end{array}$ & $\begin{array}{l}\text { Bulk } \\
\text { Density } \\
\left(\mathrm{g} / \mathrm{cm}^{3}\right) \\
\end{array}$ & $\begin{array}{c}\text { Waste } \\
\text { Density } \\
\left(\mathrm{g}_{\text {waste }} / \mathrm{cm}^{3}\right) \\
\end{array}$ & $\begin{array}{l}\text { Product } \\
\text { Volume } \\
\text { (L/day) } \\
\end{array}$ & $\begin{array}{l}\text { Product } \\
\text { Weight } \\
\text { (kg/day) } \\
\end{array}$ \\
\hline Hot-Pressed PW-9 & 100 & 3.55 & 3.55 & 83 & 294 \\
\hline Sintered PW-9 & 100 & 3.55 & 3.55 & 83 & 294 \\
\hline HIP PW-9 & 100 & 2.90 & 2.90 & 102 & 294 \\
\hline Sintered PW-9/Frit & 50 & 2.21 & 1.10 & 294 & 881 \\
\hline 76-68 Glass & 33 & 3.00 & 1.00 & 266 & 587 \\
\hline Sintered SPC-5B & 50 & 1.95 & 0.97 & 301 & 587 \\
\hline HIP SPC-5B & 50 & 1.62 & 0.81 & 360 & 587 \\
\hline \multicolumn{6}{|l|}{ Celsian Glass } \\
\hline Ceramic & 20 & 3.10 & 0.62 & 474 & 1468 \\
\hline Cement/PW-9 & 10 & 1.71 & 0.17 & 1716 & 2935 \\
\hline Cement/SPC-5B & 5 & 1.85 & 0.09 & 3173 & 5870 \\
\hline
\end{tabular}

(a) Based on $59 \mathrm{~kg}$ solid waste per MTU and processing 5 MTU/day. 
TABLE 5. Apparent Densities and Open Porosity Values of Comparative Studies Waste Forms

$\frac{\text { Waste Product }}{\text { Hot-Pressed PW-9 }}$
Sintered PW-9
Celsian Glass Ceramic
$76-68$ Glass
HIP PW-9
Sintered PW-9/Frit
Sintered SPC-5B
HIP SPC-5B
Cement/PW-9
Cement/SPC-58

$\begin{aligned} \begin{array}{c}\text { Open Porosity } \\ (\text { vol } \%)\end{array} & \frac{1.30}{2.26} \pm 1.90 \\ 13.05 & \pm 0.90 \\ <1 & <1 \\ 25.00 & \pm 0.93 \\ 6.27 & \pm 0.61 \\ 29.21 & \pm 0.60 \\ 48.14 & \pm 1.36 \\ 28.54 & \pm 0.54 \\ 25.14 & \pm 0.67\end{aligned}$

Open Porosity

Apparent Density(a)

$3.606 \pm 0.056$
$3.485 \pm 0.070$
$3.044 \pm 0.013$
$2.908 \pm 0.011$
$2.890 \pm 0.045$
$2.227 \pm 0.028$
$2.050 \pm 0.008$
$1.620 \pm 0.011$
$1.841 \pm 0.012$
$1.770 \pm 0.018$

$25.14 \pm 0.67$

(a) Immersion fluid was isopropyl alcohol 


\section{COMPARATIVE TESTING PROCEDURES}

The main objectives in the application of test procedures to the waste forms studied, were that the tests be applied equally throughout and that the resulting data be meaningful not only in terms of comparability but also in terms of waste form assessment. The three major areas of waste form testing have been identified as mechanical strength, volatility and leach resistance. All three areas provide pertinent data related to waste form stability and allow for the most relevant comparisons. Mechanical strength tests, while not addressing the impact behavior, ranks materials by a tensile load test. Volatility is examinated for conditions of both fabrication and subsequent thermal conditions, while leach resistance is evaluated in a parametric fashion.

Mechanical Strength

Comparison of mechanical strength requires a test that can be applied meaningfully throughout the wide range of glass and ceramic waste forms examined in this study. Standard procedures have been developed and used previously on the more brittle materials, which involves an impact type loading and particle size fractioning after loading (Smith 1975; Bunnell 1979). This test has not been found adequate for comparative purposes on the entire range of materials studies here since product forms such as cement and sintered calcine do not tend to "fracture" but rather agglomerate after loading. Meaningful particle size analysis is, therefore, not possible.

A secondary load to failure type test was selected to evaluate mechanical properties, and is called the Brazilian Diametral compression test (Bunnell 1979; Marion and Johnstone 1975; Spriggs et. al, 1964). In this test a right-circular cylindrical specimen is compressed diametrically between two flat platens. Maximum tensile stresses are developed normal to the loading direction across the loaded diameter and are proportional to the applied load. Under the proper conditions, these tensile stresses cause the cylinder to fracture along the diametral plane joining the lines of contact of the specimen and the platens. The tensile strength can be computed from the measured load at fracture by the formula: 


$$
\sigma=\frac{2 P}{\pi D 1}
$$

where $P$ is the applied load at fracture, $D$ is the specimen diameter and 1 is the specimen length.

Precautions must be taken with this test to insure that fracture is initiated by tensile stresses if the test is to yield useful results. High compressive and shear stresses that exist at the loading points must be minimized. This is generally accomplished by placing a thin pad of suitable material between the specimen and the loading platens. In the present work, 1/16 inch balsa wood, with its grain oriented perpendicular to the line of contact between the cylinder and platen, was used. The acceptance or rejection of a particular loading run was made based upon visual observation of the fractured cylinder using guidelines set forth in previous work (Marion and Johnstone 1975, Rudnick et. al 1963).

The materials tested were produced from either core drilled cylinders or cold pressed and sintered pellets that were centerless ground to assure roundness. Both ends were diamond saw sectioned to assure uniform length. The right circular cylinders used in this test were approximately $1.3 \mathrm{~cm}$ diameter by $1.3 \mathrm{~cm}$ long. A minimum of five specimens of each waste form type were evaluated on an Instron type tensile test apparatus at a cross head loading rate of $0.5 \mathrm{~mm} / \mathrm{min}$.

Volatility

Comparative volatility evaluations on the materials in this study were two-fold in nature. The first objective was to determine weight loss as a function of temperature as well as concentration of volatile species during the initial processing of untreated starting materials for each waste form type. The second objective was to evaluate overall weight loss of the finished product as a function of temperature within a temperature range defined by possible secondary processing conditions or accident scenario type temperatures. 
The apparatus used for volatility measurements in this work has been described in detail elsewhere (Gray 1976) and reference should be made there for specific details. In general, the furnace apparatus allows continuous recording of weight loss from the sample while a portion of the volatiles are simultaneously collected on a water-cooled cold-finger for later removal and chemical analysis. A dry air flow was passed over the surface of the specimen during the test run at a flow rate such that the vaporization rate was independent of the flow rate itself. (This corresponds to Region IV on the generalized transpiration curve [Gray 1976].) The flow rates used in the present work were $22.5 \mathrm{CFH}$. All volatility determinations made to define the processing behavior (dynamic tests), and were conducted with the furnace starting at room temperature following the specific thermal processing conditions as outlined in previous sections. Evaluations made for weight loss only on processed materials (static tests), were made by first heating the furnace to the desired temperature and then lowering the specimen into the hot zone. The former measurement was conducted at the processing temperature for the time period specified by these procedures (usually 1-2 hours), while the latter test was conducted at the desired temperatures for a time period of three hours. The temperatures used for the "static" volatility measurements were $700^{\circ}, 900^{\circ}$, $1100^{\circ}$, and $1300^{\circ} \mathrm{C}$.

Condensable vapors collected during the dynamic volatility test were removed from the cold finger, dissolved, and analyzed via atomic absorption and $x$-ray fluorescence techniques. No condensables were collected in the "static" or isochronel-isothermal case. During the "dynamic" volatility evaluation an attempt was made to standardize the mass of the sample being investigated. Due to density differences and the physical limitations of the apparatus, this was not possible. Batch sizes ranged from 2.5-5.0 grams, with glass batch the lowest and pressed PW-9 cylinders the highest. In the static measurement, samples were standardized by using right circular cylinders with nominal surface area of $472 \mathrm{~mm}^{2}$.

\section{Leach Resistance}

Static-solution leach testing was performed in such a manner on each waste form so as to evaluate the effects of time, temperature, sample surface area, 
and volume of solution on the leaching process. The leach testing array of parameters was designed to provide the minimum points required for a three dimensional statistical analysis with time, temperature and sample surface area to solution volume ratio as the principle axes, as illustrated in Figure 4. Statistical testing and analysis of this nature has been established and discussed in greater detail elsewhere (DuPont 1975), and is most commonly referred to as the Box-Behnken design.

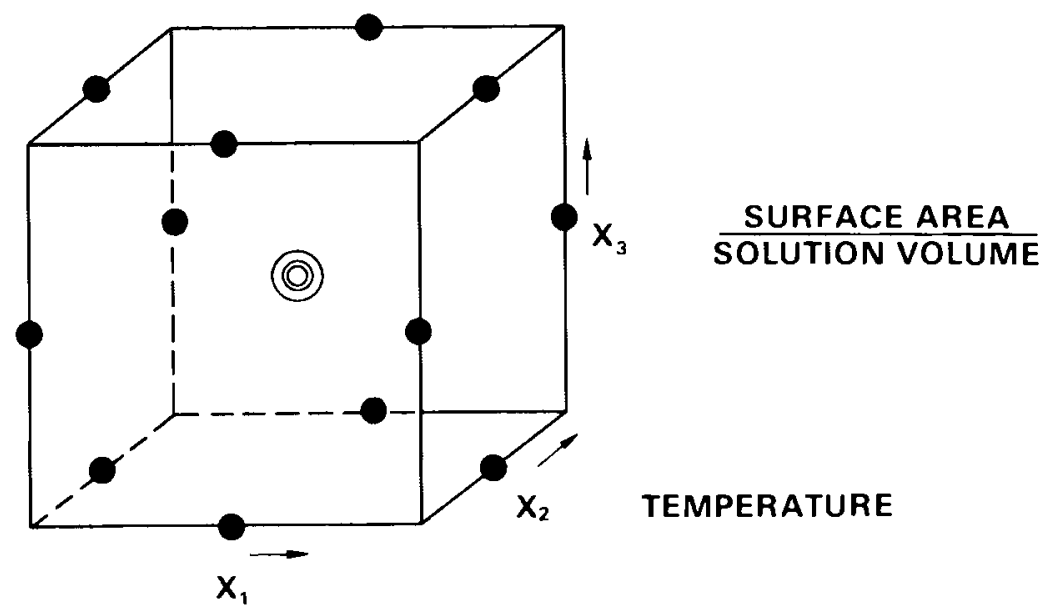

TIME

FIGURE 4. Geometry of Box-Behnken Design for Three Variables

Three temperatures were employed in these leach tests, $30^{\circ}, 90^{\circ}$, and $200^{\circ} \mathrm{C}$, covering three time periods of 1,3 , and 9 days. The surface area to solution volume ratios used covered two orders of magnitude from $0.6 \mathrm{~m}^{-1}$ to $60 \mathrm{~m}^{-1}$, with the major leachate solution being deionized water. Table 6 illustrates a schematic of parameter combinations for the described leach testing. All samples were leached in the form of right circular cylinders, uniformly core drilled or centerless ground to approximately the same diameter and cut to the length required for the desired SA/SV ratio. In some cases, more than one specimen was required to obtain the desired ratio. 


\section{TABLE 6. Time, Temperature and Surface Area to Solution Volume Ratio Combinations Used in the Comparative Leach Resistance Evaluations}

\begin{tabular}{|c|c|c|c|}
\hline Time & $30^{\circ} \mathrm{C}$ & $90^{\circ} \mathrm{C}$ & $200^{\circ} \mathrm{C}$ \\
\hline 1 day & $6 \mathrm{~m}^{-1}$ & $\begin{array}{l}0.6 \\
60\end{array}$ & 6 \\
\hline 3 day & $\begin{array}{l}0.6 \\
60\end{array}$ & $6(3 x)$ & $\begin{array}{l}0.6 \\
60\end{array}$ \\
\hline 9 day & 6 & $\begin{array}{l}0.6 \\
60\end{array}$ & 6 \\
\hline
\end{tabular}

(3x) Three set replication

The samples were cleaned in acetone and alcohol prior to testing, and placed on their sides in solution in plastic polymethylpentane (PMP) containers with plastic screw tops. The plastic containers and tops had been previously thoroughly cleaned in a dilute solution of high purity nitric acid and deionized water then rinsed several times in deionized water. At the completion of the leach testing period, the samples were removed from the solution with teflon forceps, dried and weighed, and the solution sent directly for analysis. The $\mathrm{pH}$ of each solution is measured and then induction coupled plasma (ICP) spectroscopy is employed to determine the majority of elements while cesium analys is was performed by atomic emission.

The elements selected for use in comparing waste form leaching behavior were $\mathrm{Na}, \mathrm{Cs}, \mathrm{Mo}, \mathrm{Si}, \mathrm{Ca}, \mathrm{Sr}, \mathrm{Al}$, and $\mathrm{B}$. These elements are present in nearly all waste forms and are either among the most mobile simulated fission product elements or represent the non-fission product additive constituents. Some elements, such as $\mathrm{Cs}$ and $\mathrm{Sr}$ are among the more hazardous fission products and others such as $\mathrm{Si}, \mathrm{Al}$, and $\mathrm{B}$ provide a measure for the integrity of additive components in glass-based or supercalcine waste forms. 
The analytical results were recalculated in terms of normalized grams of a given element released per meter squared of geometric sample surface area using the expression:

$$
\text { norm } g / \mathrm{m}^{2}=\frac{M i}{F_{i} \times S A}
$$

where $\mathrm{Mi}=$ mass of element in leachate $(\mathrm{g})$

$\mathrm{Fi}=$ weight fraction of element in waste form

$\mathrm{SA}=$ geometric surface area of sample $\left(\mathrm{m}^{2}\right)$

This unit was selected because it allows comparison of waste-form leachability regardless of waste loading. Note that this unit is not a leach rate but is the total amount of a given element leached in the indicated time period. 


\section{COMPARATIVE TEST RESULTS AND ANALYSIS}

Although there was a total of ten waste forms fabricated for comparative testing purposes, it was not possible to apply all tests to all materials as data in the following sections illustrate. Hot-isostatically-pressed materials cracked extensively during preparation and it was not possible to obtain suitable specimens for mechanical testing. Volatility evaluations during fabrication could be performed on all the high temperature process materials except the hot-pressed and hot-isostatically-pressed materials because of the process equipment considerations. Secondary volatility evaluations on fabricated waste forms between the temperatures of $700^{\circ}$ and $1300^{\circ} \mathrm{C}$ could only be meaningfully applied to six of the waste forms. The cement based waste forms lost over $20 \%$ of their initial weight when heated in this range while the PW-9 plus 50\% frit samples foamed severely at temperatures much above $900^{\circ} \mathrm{C}$. Hot pressed PW- 9 samples were observed to shatter spontaneously no matter how slowly they were lowered into a pre-heated furnace. It was possible to leach test all of the materials produced; however, even though a statistical leach test design was attempted it was not entirely successful. Even though the results obtained do illustrate trends, the interaction of parameters is not as well defined as was originally intended.

Mechanical Strength

Diametral compression test results for eight of the waste forms available for testing in this study are illustrated in Figure 5 . The average statistical standard deviation observed was $\pm 17 \%$ which is typical of the nature of brittle ceramics. Sintered PW-9 and the cement matrix materials have the lowest strength values of the materials measured, but with the application of hot pressing, or the addition of $50 \%$ of a glass forming frit, the average strength values for the calcine waste form PW-9 can be increased by about $60 \%$. The next broad category of mechanical strength also coincides with the waste forms whose processing conditions are in some cases more detailed than simple consolidation as in the previous forms. This category which includes supercalcine, glass ceramic, and glass, exhibits a strength increase over the next lower grouping of from $120 \%$ to $290 \%$. 


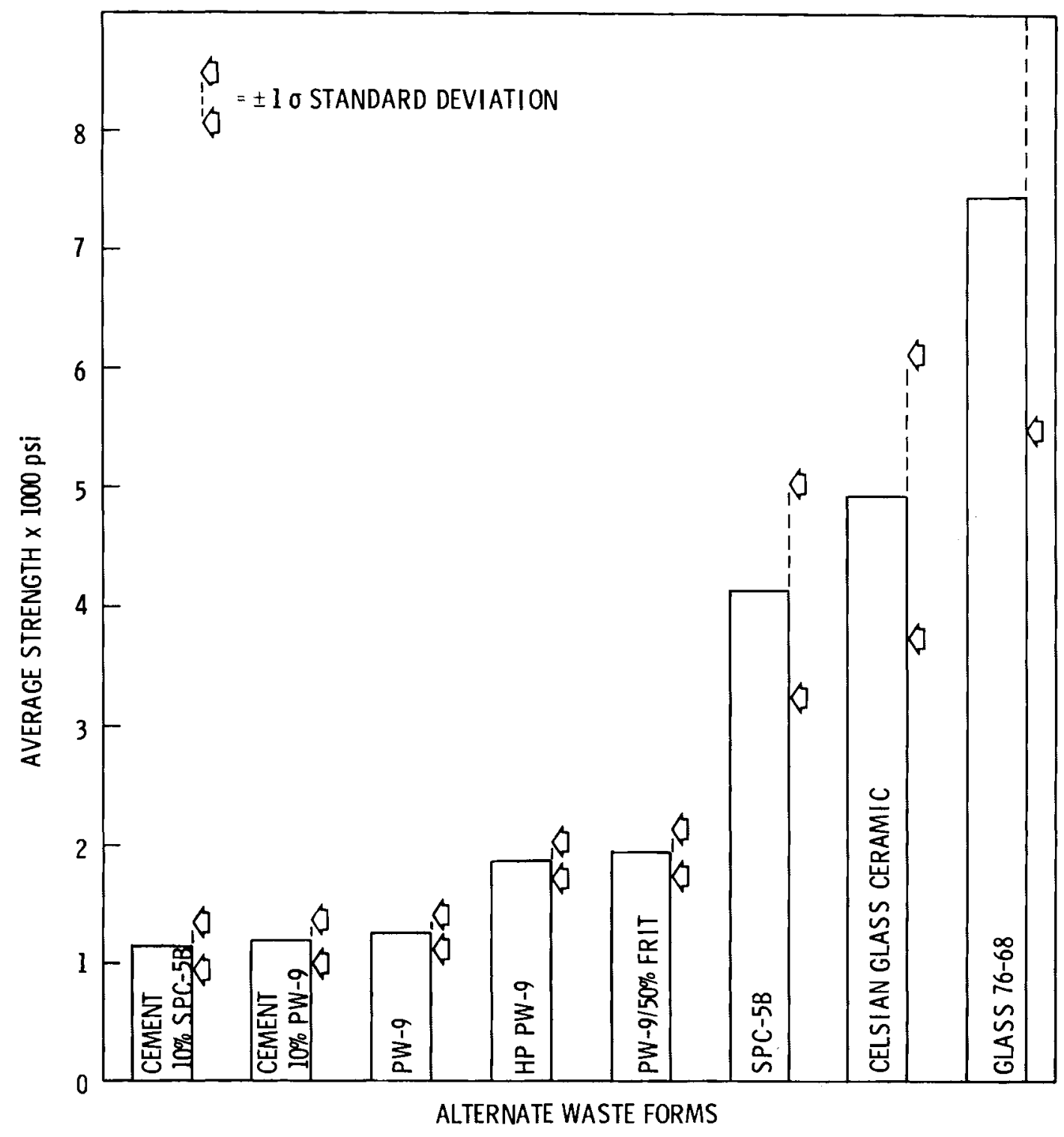

FIGURE 5. Diametral Compression Test Results for Eight Ceramic and Glass Alternative Waste Forms

The analysis of mechanical behavior of ceramic and glass materials is difficult because it is well established that fracture behavior is effected by surface and volume defects, sample size, load rate and test procedure at a minimum. Fracture does not generally occur by one simple process for all 
materials and conditions but rather by a number of quite different mechanisms. The main scope of this analysis, though, is one of comparison of waste forms rather than a detailed investigation of fracture mechanisms.

The major effect on mechanical properties in most ceramics is the result of bulk total porosity (open and closed pores) because pores not only decrease the cross-sectional area on which the load is applied, but also act as stress concentrators. Table 7 compares the average compressive strength and porosity for the eight waste forms evaluated in this study. It appears clear from this table that a more complex cause of failure in these materials indeed exists. In the materials tested there is no clear one to one correlation between the measured strength ratings and the porosity values. It might be more reasonable to expect a combined effect of porosity and bulk microstructure.

Cement and sintered calcine products consist of a relatively weak mechanical agglomeration of discrete particles where no sintering or extensive grain growth has occured and result in a lower observed mechanical strength. When hot pressing or a glassy matrix former is added, an increase in particle agglomeration occurs with a corresponding increase in mechanical strength. Supercalcine, glass ceramic and glass, which have the highest strength, seem to illustrate even more clearly the enhanced effects when there is a strong matrix effect.

TABLE 7. Estimated Total Porosity Values and Mechanical Strength Values for Eight Comparative Study Materials

\begin{tabular}{|c|c|c|}
\hline Waste Form & $\begin{array}{c}\text { Est. Total } \\
\text { Porosity }\end{array}$ & $\begin{array}{c}\text { Mechanical } \\
\text { Strength } \\
\end{array}$ \\
\hline Cement $+10 \% \mathrm{PW}-9$ & $30 \%$ & 1210 psi \\
\hline Cement $+10 \%$ SPC $-5 B$ & $30 \%$ & 1139 \\
\hline SPC-5B Supercalcine & $30 \%$ & 4155 \\
\hline $50 \%$ frit $+50 \% \mathrm{PW}-9$ & $25 \%$ & 1953 \\
\hline Sintered PW-9 & $25 \%$ & 1276 \\
\hline HIP PW-9 & $10 \%$ & 1883 \\
\hline Celsian Glass Ceramic & $<1 \%$ & 4969 \\
\hline G1 ass $76-68$ & $<1 \%$ & 7465 \\
\hline
\end{tabular}


The increased strength of supercaline is probably due to increased physical bonding resulting from the ingrowth of crystalline phases and the interaction with an amorphous phase. Glass ceramics, on the other hand, are generally considered to have higher mechanical strengths than ordinary glasses or conventional ceramics. This was not observed in the celsian glass ceramic. Usually in a glass ceramic, fine crystallites, uniformly dispersed in the product, produce a comparatively homogenous stress distribution. The actual strength, however, will be critically influenced by not only fine crystallites uniformly dispersed, but also by (a) the types, amount, and orientation of crystals, (b) inherent coherence of the crystal-glass (or matrix) boundary and intersurface conditions, and (c) variable glass compositions in the matrix. Any one of these parameters could have adversely efected the celsian glass ceramic. The 76-68 glass form represents a matrix containing less defects than the ceramic materials, with the continuum of vitreous material providing the main basis of the high strength.

From the standpoint of overall mechanical behavior, the optimum condition is seen to exist through either a glass, glass-ceramic or crystallized ceramic processing. Those processes are found to provide up to $290 \%$ improvement in strength, as measured by diametral compression, over the considerably simpler processes of cementation or cold press and sintering.

Volatility

Dynamic Measurements

Volatile losses during typical processing conditions of five waste forms are illustrated in Figure 6 . These curves are typified by a plateau region from about $200^{\circ} \mathrm{C}$ to $500^{\circ} \mathrm{C}$, which indicates the initial loss of water and residual nitrates. Losses from $500^{\circ} \mathrm{C}$ to $700^{\circ} \mathrm{C}$ are principally due to nitrates. Actual waste form volatile loss begins above about $700^{\circ} \mathrm{C}$. Total estimated condensable (CS, Te, Ru, etc.) and non-condensable (i.e. water and nitrates) fractions for the five materials evaluated during processing are given in Table 8. The differences in the amount of non-condensables between waste forms illustrates an effect beyond that expected by waste loading alone; this factor plays a more important role in the handling of process offgasses. 


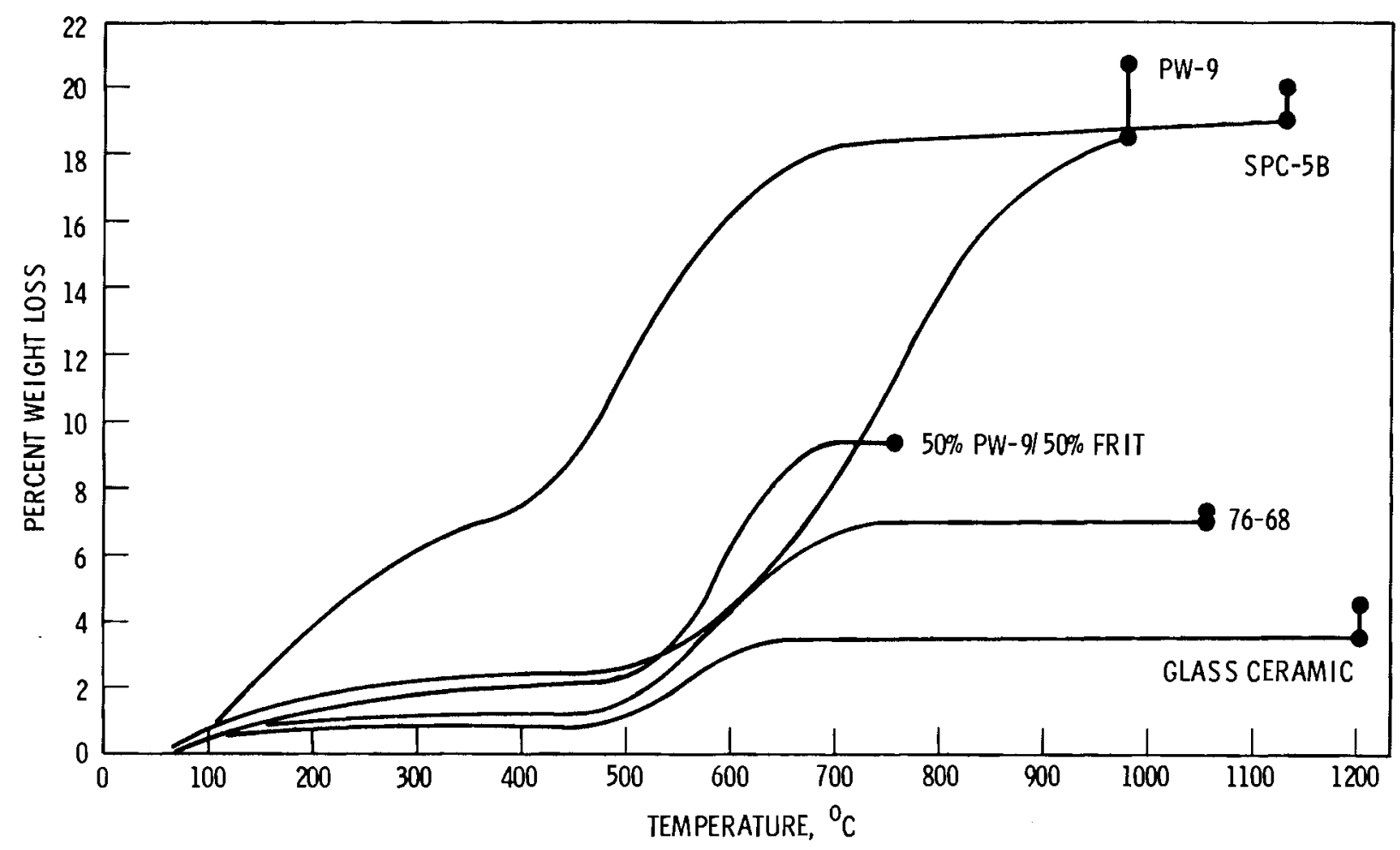

FIGURE 6. Volatility During the Preparation of Various Alternative Waste Forms

TABLE 8. Average Fraction of Condensable and Non-Condensable Volatiles Released from Five Waste Forms During Processing

\begin{tabular}{|c|c|c|c|}
\hline Waste Form & $\begin{array}{c}\text { Condensable } \\
\% \\
\end{array}$ & $\begin{array}{c}\text { Non-Condens able } \\
\%\end{array}$ & $\begin{array}{c}\text { Total } \\
\% \\
\end{array}$ \\
\hline PW-9 & 2.07 & 18.46 & 20.53 \\
\hline$S P C-5 B$ & 1.51 & 18.51 & 20.02 \\
\hline $\begin{array}{l}\text { Celsian Giass } \\
\text { Ceramic }\end{array}$ & 0.78 & 3.79 & 4.57 \\
\hline Gl ass $76-68$ & 0.32 & 6.90 & 7.22 \\
\hline PW-9 $+50 \%$ Frit & 0.08 & 9.33 & 9.41 \\
\hline
\end{tabular}


Table 9 illustrates the concentration of the major volatile species measured in the collected consensable off gas. In this type of cold finger collection, all of the offgas is not collected. It is estimated that the collected material represents approximately $50 \%$ of the total quantity of condensables. It should be recognized that in comparison of the results of one material to another in this analysis, the error bars may be large.

The elements listed in Table 9 represent the major elements, principally from the waste stream calcine, that are most susceptable to volatilization. In general, sodium, ruthenium, telurium, and cesium are the major volatile components. It is noteworthy, though, that condensable losses are not found to follow strictly with processing temperature, but rather other factors related to the waste form play an important role. Two factors seem to predominate in the overall analysis: Processing temperature and waste form constitution. It is clear from the present work that the waste form with the lowest processing temperature will be the best from the standpoint of low volatile release.

TABLE 9. Relative Amounts of Condensable Volative Species Collected in the Offgas Stream During Processing

\begin{tabular}{|c|c|c|c|c|c|}
\hline & $\begin{array}{c}50 \% \text { Frit }+ \\
50 \% \text { PW-9 } \\
\end{array}$ & PW-9 & $\begin{array}{l}\text { Glass } \\
76-68 \\
\end{array}$ & $S P C-5 B$ & $\begin{array}{c}\text { Celsian Glass } \\
\text { Ceramic } \\
\end{array}$ \\
\hline$B$ & $0.45 \mu \mathrm{g}$ & $0.95 \mu \mathrm{g}$ & $82 \mu g$ & $3 \mu \mathrm{g}$ & $1,405 \mu \mathrm{g}$ \\
\hline $\mathrm{Na}$ & 36 & 3748 & 405 & 670 & 2,030 \\
\hline $\mathrm{Rb}$ & 16 & 2337 & 41 & 315 & 905 \\
\hline K & $<110$ & $<170$ & $<175$ & $<410$ & 2,210 \\
\hline Mo & $<6$ & 8 & 11 & 45 & 295 \\
\hline Ru & $<225$ & $<245$ & $<190$ & 11,340 & 1,665 \\
\hline Te & $<200$ & $<250$ & 325 & 6,850 & 2,540 \\
\hline Cs & 500 & 64,500 & 890 & 4,260 & 11,900 \\
\hline $\begin{array}{l}\text { Processing } \\
\text { Temperature }\end{array}$ & $750^{\circ} \mathrm{C}$ & $975^{\circ} \mathrm{C}$ & $1050^{\circ} \mathrm{C}$ & $1125^{\circ} \mathrm{C}$ & $1200^{\circ} \mathrm{C}$ \\
\hline $\begin{array}{l}\text { Processing } \\
\text { Time }\end{array}$ & $2 \mathrm{hr}$ & $2 \mathrm{hr}$ & $2 \mathrm{hr}$ & $2 \mathrm{hr}$ & $2 \mathrm{hr}$ \\
\hline
\end{tabular}


Straight calcine (PW-9), cold pressed and sintered, is subject to rather large losses of sodium and cesium, however, when this calcine is mixed with $50 \%$ of a glass forming frit and the processing temperature is lowered by $250^{\circ} \mathrm{C}$, losses of sodium and cesium drop to just detectable limits. This result is far below that which might be predicted from a straight dilution effect. Supercalcine, a higher temperature ceramic form, also $50 \% \mathrm{PW}-9$, that is not subject to melting during processing, again shows rather sizeable losses of ruthenium, tellurium and cesium during the processing stage. These losses reflect the effect of a significantly higher processing temperature on volatile losses overriding potential matrix effects.

In the ceramic waste forms, where processing does not require that the waste form be in a molten state, losses can be expected to occur from elements in the near surface region, prior to or in the early periods of the consolidation stage. Glass type waste forms, on the other hand, which are in a molten stage during one or more phases of their processing might be expected to contribute to volatilization from not only the near surface but also the bulk. This does not seem to have played a major role in the present analysis, though, as the glasses in general had a lower overall volatile loss than either PW-9 or SPC-5B. In this case, the added factor of increased bulk diffusion in the molten glass was less important than the large effective surface area in the ceramic samples. Glass 76-68 exhibited good retention of the glass constituents with the major releases seen for sodium, tellurium and cesium. The celsian glass ceramic, on the other hand, did show sings of glass component loss as well as poor retention of sodium, ruthenium, tellurium and cesium. For the processing temperature, the glasses had a lower volatile release than might be predicted from a straight dilution of PW-9 calcine.

Isothermal Measurements

Isothermal - isochronal (static) volatility measurements for six of the waste forms studied here are illustrated in Figure 7 . Cement samples were not included in this test because of the general non-applicability of the temperature required to those specific waste forms. Measurements have indicated a constant weight loss of about $20 \%$ for both cement forms through the entire 


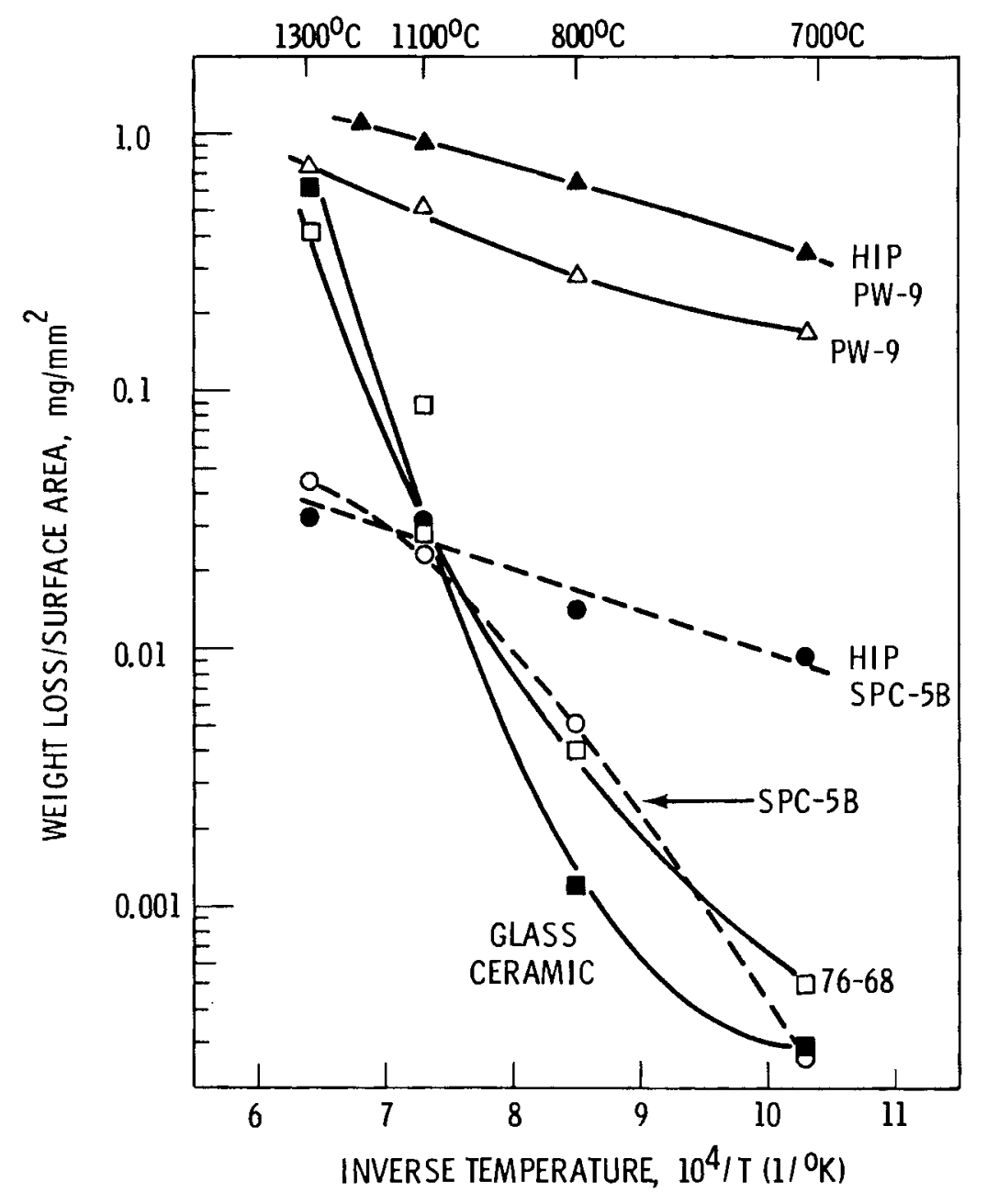

FIGURE 7. Isothermal Volatility Measurements Made on Previously Fabricated Comparative Studies Materials Held at Temperature for 3 Hours

temperature range studied. Volatility measurements on both hot pressed PW-9 calcine and PW-9 plus 50\% frit were not included due to experimental problems as discussed previously.

Cold pressed and sintered as well as the HIP PW-9 calcine have the largest volatile loss of the materials tested. It would seem that for elevated temperature processed waste forms, some matrix former is required to reduce subsequent volatile loss. The glass, glass-ceramic, and supercalcine waste forms are at least two orders of magnitude lower in subsequent volatile loss, when 
compared to $\mathrm{PW}-9$ calcine, at temperatures of $1000^{\circ} \mathrm{C}$ or lower. When the glasses approach or exceed their melting points, volatile losses increase markedly but are still below that of the straight calcine, even at $1300^{\circ} \mathrm{C}$.

Supercalcine does not tend to show larger increases in losses with increased temperature. This probably illustrates the differences between surface diffusion controlled loss and bulk diffusion controlled losses. Both HIP processed waste forms exhibited poorer performance than their cold pressed and sintered counterparts most likely as a result of incomplete densification. The differences are not large for $\mathrm{PW}-9$ with only a factor of two difference throughout, however, with SPC-5B, the HIP sample was almost two orders of magnitude poorer at the low temperature end and almost identical at the high temperature end. This may have resulted from simultaneous consolidation during testing.

The results of comparative volatility testing on the materials evaluated in this study have indicated that first, and most obviously, the lower the processing temperature the lower the volatile losses. Also implied from this testing is that a waste stream incorporated within a matrix, whether that be crystalline or glass, will have reduced volatile losses, in both processing and subsequent heat treatment, when compared to the straight calcine waste stream. Under these criteria, the best waste form studied from a volatility standpoint, was that of the $\mathrm{PW}-9+50 \%$ frit, which employed both a low processing temperature $\left(750^{\circ} \mathrm{C}\right)$ and a matrix former (glass frit). These criteria cannot be considered absolute, however, as a point in case is this waste form. Subsequent heatings above the preparation temperature caused severe foaming and an apparent loss of all previous benefits gained. These volatility tests have illustrated quite clearly that a single property evaluation cannot determine the overall waste form merit, but rather the synergistic effects of all physical properties must be considered.

Leach Resistance

Static Leach Tests

Leach results for all waste-forms studied are compared in Table 10. They represent the central point of the Box-Behnkin experimental design so that the following leach conditions were used for all samples: temperature, $90^{\circ} \mathrm{C}$; time, 
TABLE 10. Leach Resistance of Selected Alternative Waste Forms

\begin{tabular}{|c|c|c|c|c|c|c|c|c|c|}
\hline & & & & & $\mathrm{rmal}$ & ed In & ution, & & \\
\hline & $\mathrm{pH}$ & $\mathrm{Ca}$ & A1 & $\bar{B}$ & $\mathrm{Si}$ & $\mathrm{Na}$ & Mo & $S r$ & Cs \\
\hline Glass $76-68$ & 9.1 & 2 & - & 20 & 15 & 23 & 19 & 0.5 & 17.8 \\
\hline $\begin{array}{l}\text { Celsian Glass } \\
\text { Ceramic }\end{array}$ & 8.1 & 9 & 3 & 22 & 6 & 13 & 25 & 12 & 11 \\
\hline Glass Frit/PW-9 & 7.4 & 4 & 4 & 20 & 10 & 100 & 57 & 12 & 3 \\
\hline Cement/PW-9 & 11.8 & 43 & 19 & - & 480 & 4,320 & 98 & 189 & 2,570 \\
\hline $\begin{array}{l}\text { Cold Pressed } \\
\text { PW-9 }\end{array}$ & 12.6 & - & - & - & - & 9,271 & 10,460 & 1 & 6,875 \\
\hline $\begin{array}{l}\text { Cold Pressed } \\
\text { SPC-5B }\end{array}$ & 9.5 & 2 & 11 & - & 20 & 75 & 70 & 1 & 2 \\
\hline
\end{tabular}

Test Conditions: Deionized Water $90^{\circ} \mathrm{C}, 3 \mathrm{~d}, \mathrm{SA} / \mathrm{SV}-6 \mathrm{~m}^{-1}$

3 days; SA/SV (surface area to solution volume), $6.0 \mathrm{~m}^{-1}$. Three replicate tests were conducted for each sample and the average standard deviation based on these replications was $\pm 5 \%$ of the reported value.

In general, the glass, glass-ceramic, and supercalcine samples demonstrate excellent leach resistance for all elements considered. The cold pressed and hot pressed PW-9 calcine samples have very high leach values for $\mathrm{Na}$, Mo, and Cs but a low value for $\mathrm{Sr}$. The elements $\mathrm{Ca}, \mathrm{Al}, \mathrm{B}$, and $\mathrm{Si}$ are not present in PW-9. Leach resistance is greatly improved for PW-9 when sintered with 50ه glass frit. No significant improvement in leachability is obtained by hot pressing supercalcine, SPC-5B, as compared with cold pressing and sintering. It is interesting that the concrete waste-forms yield similar leachabilities regardless of whether PW-9 calcine or SPC-5B supercalcine is added. This suggests that these additives might be altered during similar cement hydrolysis and hydration processes.

The effects of both processing conditions and additives on PW-9 calcine are shown in Table 11. Hot isostatic pressed (HIP) PW-9 shows lower leachability for $\mathrm{Na}$ and Mo than either the cold pressed and sintered or hot pressed 
TABLE 11. Comparison Leach Resistance of PW-9 Waste Forms

\begin{tabular}{|c|c|c|c|c|c|c|c|c|c|}
\hline \multirow{2}{*}{$\begin{array}{c}\text { Fabrication } \\
\text { Method }\end{array}$} & \multicolumn{9}{|c|}{ Normalized In Solution, $\mathrm{g} / \mathrm{m}^{2}$} \\
\hline & $\mathrm{pH}$ & $\overline{\mathrm{Ca}}$ & A] & B & Si & $\mathrm{Na}$ & Mo & $S r$ & $\mathrm{Cs}$ \\
\hline Cold Pressed & 12.6 & - & - & - & - & 9,271 & 10,460 & 1 & 6,875 \\
\hline Hot Pressed & 10.9 & - & - & - & - & 6,814 & 5,550 & 4 & 4,685 \\
\hline $\begin{array}{c}\text { Hot Isostatic } \\
\text { Pressed }\end{array}$ & 10.5 & - & - & - & - & 2,332 & 2,366 & 1 & 16,960 \\
\hline Type II Cement & 11.8 & 43 & 19 & - & 480 & 4,320 & 98 & 189 & 2,570 \\
\hline Glass Frit (50\%) & 7.4 & 4 & 4 & 20 & 10 & 100 & 57 & 12 & 12 \\
\hline
\end{tabular}

Test Conditions: Deionized Water

$$
90^{\circ} \mathrm{C}, 3 \mathrm{~d}, \mathrm{SA} / \mathrm{SV}-6 \mathrm{~m}^{-1}
$$

material but the opposite effect is observed for Cs. Leach rates calculated on the basis of analysis of these materials after fabrication do not account for this observation. Consequently, these data suggest that processing techniques effect leach behavior possibly through unexpected phase formation not readily detected by routine $x$-ray diffraction methods. The hot pressed and HIP samples were prepared under anoxic or even reducing conditions relative to the air sintered samples. This difference in redox conditions could lead to changes in element distribution among oxide phases as we11 as more reduced states for elements such as $\mathrm{Cr}$ and Mo than the more oxidized +3 and +6 respectively. Partial support for these suggestions are shown by the higher leach data for Mo and also $\mathrm{Cr}$ (not reported here) in the cold pressed samples compared with the others and in the higher values for Cs in the HIP samples.

Many of the PW-9 samples lost their structural integrity during leaching to the extent that the solutions had to be filtered before analysis. This behavior did not occur when PW-9 was added to either cement $(10 \%$ PW-9) or glass 
frit ( $50 \% \mathrm{PW}-9)$. Considerable improvement in leach behavior was also observed for these additive forms with the glass frit additive producing the best element retention.

A comparison of cold pressed and sintered with hot pressed supercalcine, SPC $-5 B$ as well as the effects of a cement additive is presented in Table 12. These data suggest that no improvement is obtained by hot pressing supercalcine rather than sintering. The cement additive results in a less durable product. As mentioned previously, it is suggested that this behavior may be the result of the decomposition of SPC-5B phases during cement hydrolysis that may lead to a redistribution of elements as solid solution components in calcium aluminosilicates or as components of discrete secondary phases.

TABLE 12. Comparison of Leach Resistance of SPC-5B Waste Forms

\begin{tabular}{|c|c|c|c|c|c|c|c|c|}
\hline Fabrication & & & & emen & Solu & $g / r$ & & \\
\hline Method & $\mathrm{pH}$ & $\underline{\mathrm{Ca}}$ & Al & $\underline{\mathrm{Si}}$ & $\mathrm{Na}$ & Mo & $\underline{S r}$ & $\mathrm{CS}$ \\
\hline Cold Pressed & 9.5 & 2 & 11 & 20 & 75 & 70 & 1 & 2 \\
\hline $\begin{array}{l}\text { Hot I sostatic } \\
\text { Pressed }\end{array}$ & 8.5 & 16 & 8 & 13 & 75 & 52 & 3 & 3 \\
\hline Type II Cement & 11.9 & 27 & 21 & 444 & 5090 & 140 & 440 & 2120 \\
\hline
\end{tabular}

Effects of Time, Temperature, and SA/SV

The concentrations of $\mathrm{Na}, \mathrm{Mo}$, and $\mathrm{Cs}$ in solutions of static leach tests can be used to illustrate the effects of time, temperature, and surface area to solution volume ratio (SA/SV) on leaching behavior. Figure 8 shows these data for HIP PW-9 calcine with concentration expressed as normalized grams of element leached per square meter of surface area. The SA/SV ratios used in this study were $60 \mathrm{~m}^{-1}$ (lower line) and $0.6 \mathrm{~m}^{-1}$ (upper line). If the concentration differences of an element leached from a waste form at a specified time and temperature using these two SA/SV ratios are the result of dilution effects only, they should differ by two orders of magnitude. In terms of normalized concentrations the following relation holds: 
HIP PW-9
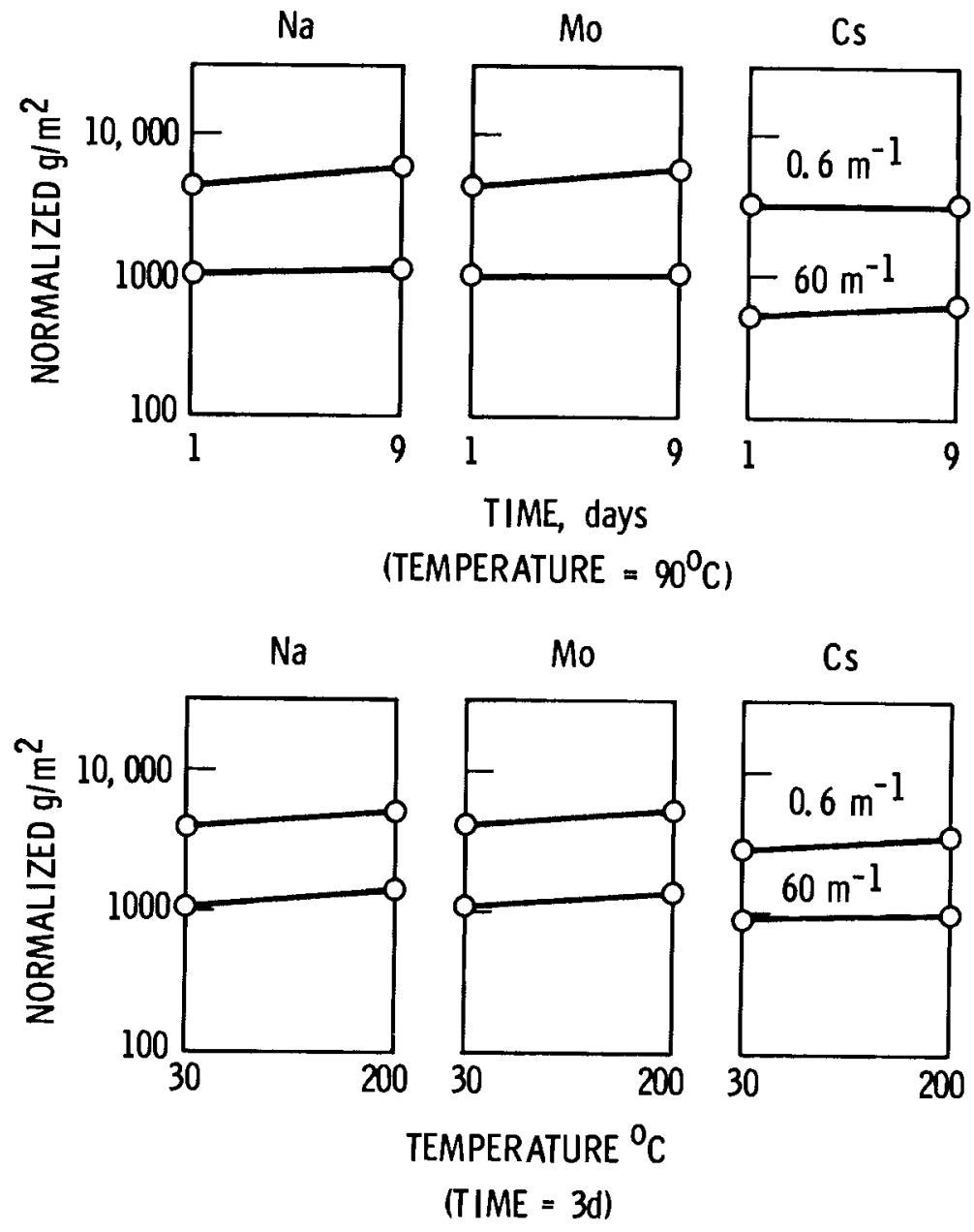

FIGURE 8. Effect of Time, Temperature, and SA/SV on Leach Resistance of Hot Isostatic Pressed PW-9

$$
\frac{C(p p m)\left[\Theta S A / S V=0.6 \mathrm{~m}^{-1}\right]}{0.6}=\frac{C(p p m)\left[0 \mathrm{SA} / \mathrm{SV}=60 \mathrm{~m}^{-1}\right] * 100}{60}
$$

Consequent1y, if the SA/SV ratio has no effect on leachability, the normalized concentrations from the two samples should be equal. In Figure 8 , the normalized concentrations of $\mathrm{Na}$, Mo, and $\mathrm{Cs}$ from the HIP PW-9 samples are separated by approximately a factor of 5 or 6 suggesting that the solutions from the low SA/SV ratio tests are undersaturated with respect to the higher ratios. The 
normalized concentrations of these elements are also approximately parallel with the abscissa indicating that neither time nor temperature has an effect on leaching behavior within the range of parameters studied.

In contrast with the HIP PW-9 samples, the effects of these same leaching parameters for $\mathrm{Na}$, Mo, $\mathrm{Si}$, and $\mathrm{Cs}$ in 76-68 glass are shown in Figure 9. In 76-68 glass all parameters seem to have an effect on the leaching behavior of all elements. Because these lines are non-parallel there is also interaction effects among the variables and concentration differences cannot be attributed to dilution effects alone. The effects of time seem to be greater at high SA/SV ratios and negligable at lower ratios although temperature has the same effect on both. At the lowest times and temperatures, the observation of identical concentrations at both SA/SV ratios suggests that solubility may be a limiting control at these conditions. This general behavior seems to be characteristic of glass-based waste forms as opposed to waste forms containing a large proportion of fission products as oxides.

Ceramic-type waste forms seem to be intermediate in behavior between calcine and glass based waste-forms as shown in Figure 10 for all cold pressed SPC-5B. Release of elements such as $\mathrm{Na}$ and Mo are not affected kinetically as much as by temperature, while $\mathrm{Si}$ is affected by both parameters. Cs release seems to be slightly influenced by temperature, but not by time and the near coincidence of concentration suggests a solubility control.

The $\mathrm{pH}$ measurements of leachate solutions (Figure 11) from these wasteform types do not necessarily exhibit the same behavior observed for fission product release. The $\mathrm{PW}-9$ leachate $\mathrm{pH}$ measurements exhibit about the same type of behavior observed for fission product release. This is expected if leachate $\mathrm{pH}$ is generally the result of hydrolysis of basic anhydride oxide components. A similar behavior is observed for SPC-5B, but with some modification. There is approximately two $\mathrm{pH}$ units difference in $\mathrm{pH}$ which roughly corresponds to the two SA/SV ratios but pH values are lower. This could possibly be attributable to the buffering capacity of additive components. The effect of matrix constituents in buffering the solution $\mathrm{pH}$ is even more pronounced in the cementbased waste forms. Cement pH's appear to be largely controlled by hydrolysis 

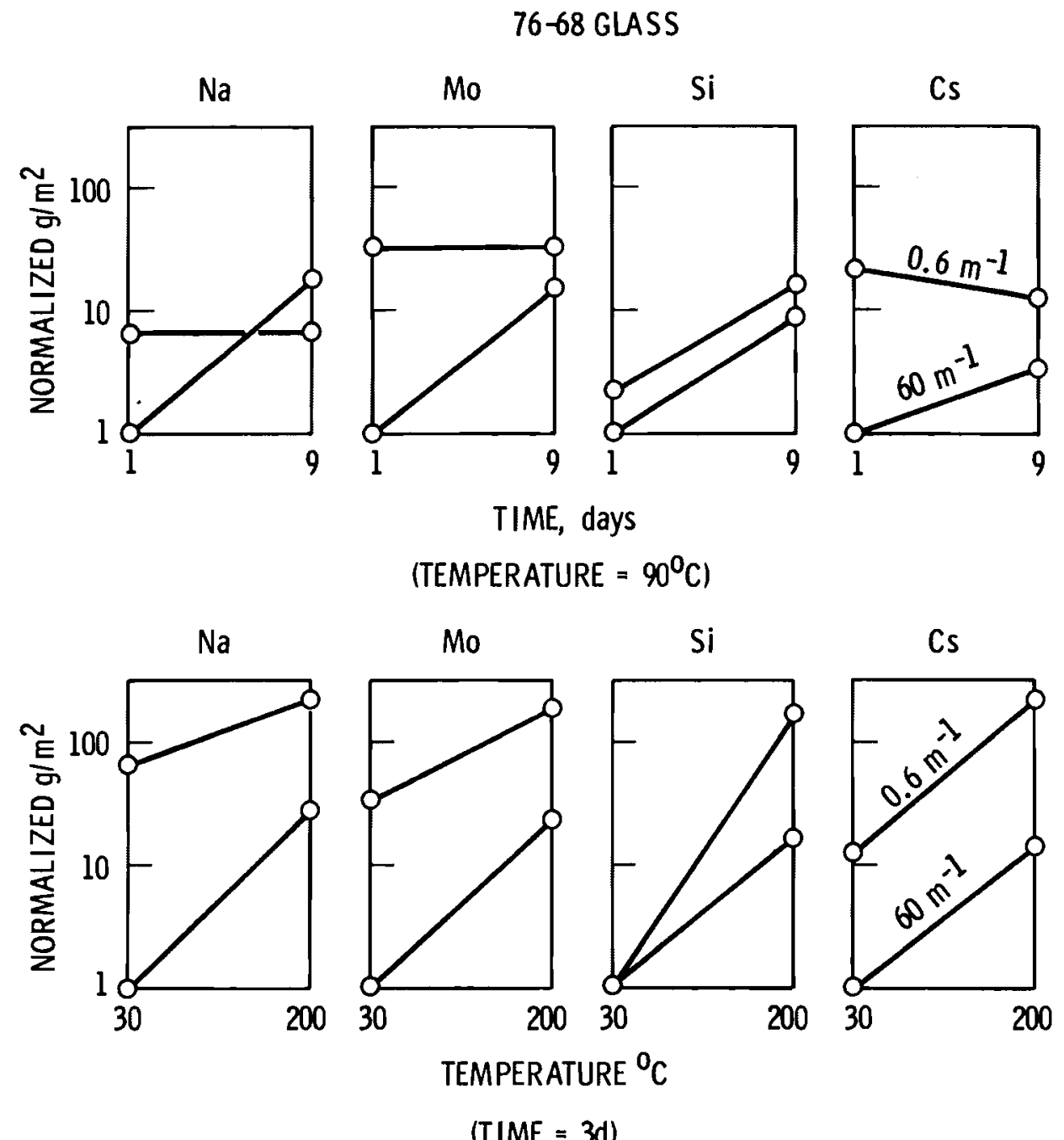

FIGURE 9. Effect of Time, Temperature, and SA/SV on Leach Resistance of 76-68 Glass 
SPC-5B
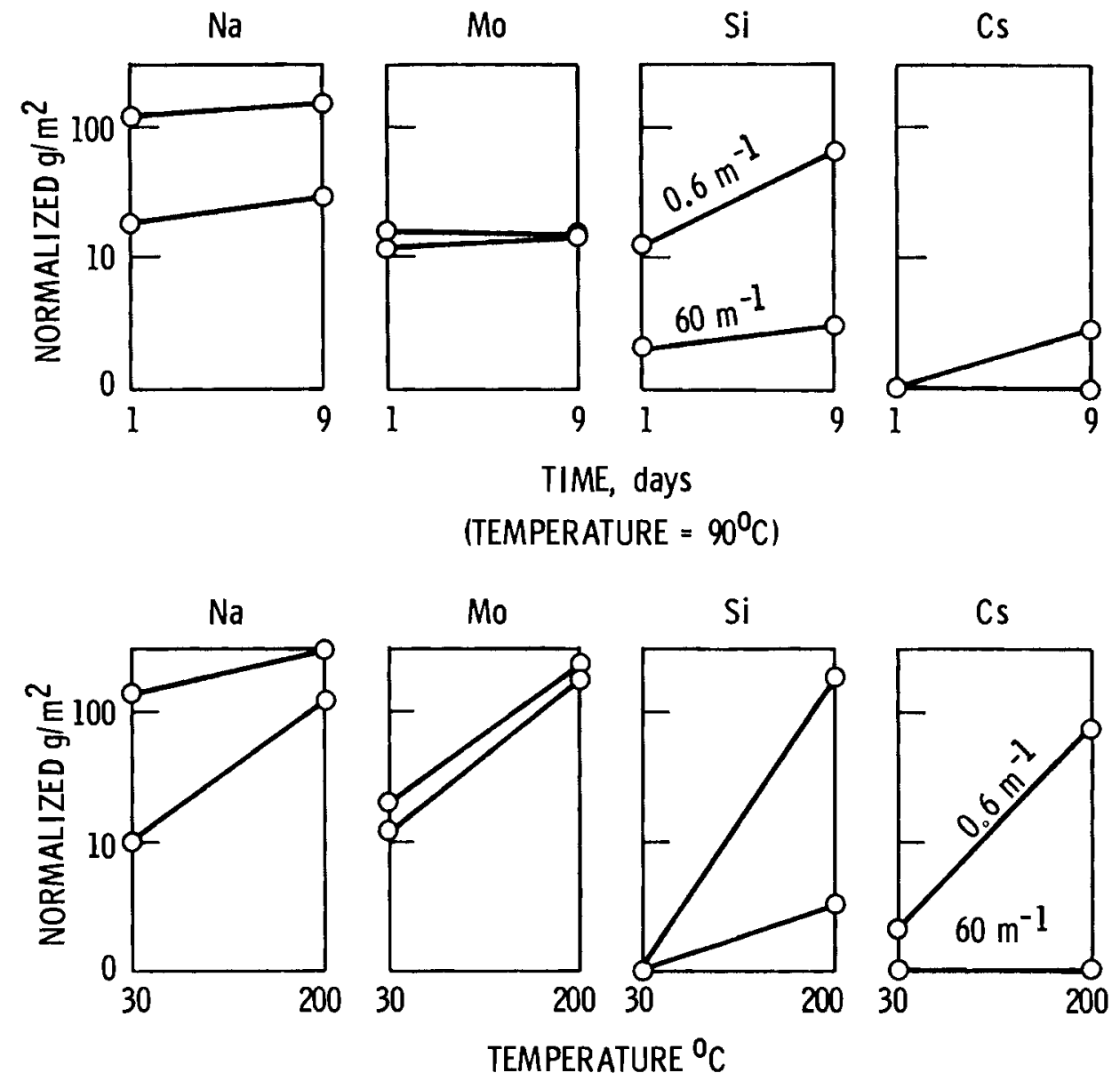

TEMPERATURE ${ }^{\circ} \mathrm{C}$

$(T I M E=3 d)$

FIGURE 10. Effect of Time, Temperature, and SA/SV on Leach Resistance of Hot Isostatic Pressed SPC $-5 B$ 


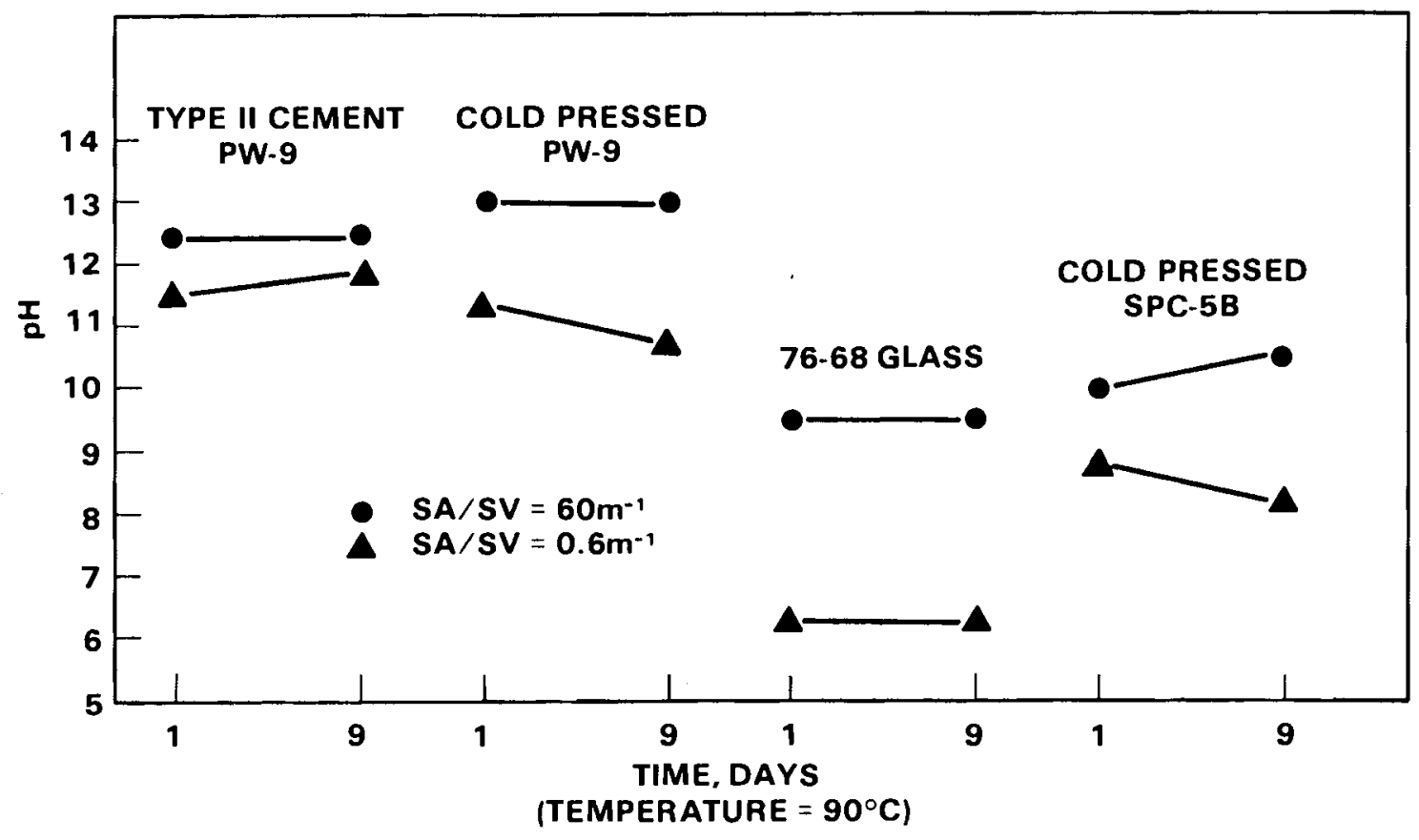

FIGURE 11. Effect of Time, Temperature, and SA/SV on $\mathrm{pH}$ of Leachate for Selected Waste Forms

products of cement components such as $\mathrm{Ca}(\mathrm{OH})_{2} \cdot \mathrm{Glass}$ leachant pH values also exhibit a matrix effect that is not as pronounced as cement probably because of the greater resistance to hydrolysis of glass matrix components compared with cement. As a result, glass $\mathrm{pH}^{\prime}$ s show an effect of dilution, but are not directly related to fission product release.

This study was designed as a preliminary investigation not only to compare the leaching behavior of alternative waste forms but to gain some insight into effects of common leach test parameters. In this perspective, some general conclusions are apparent that may warrant more detailed investigation. The effects of leaching parameters, particularly time and temperature, on fission product release are more pronounced for the more durable waste forms. The significance of waste loading was not directly addressed, but must be considered in the context of matrix components because fission product release is in part a function of matrix durability. In addition, waste-matrix interaction 
mechanisms during waste loading and processing may lead to an undesirable distribution of fission products among crystalline waste form assemblages. An evaluation of the magnitude of leach parameter variation would require a more detailed statistical design model. This study suggests that such an effort would be beneficial if conducted with some of the more durable waste forms and could lead to improved process control specifications as well as better waste form evaluation. 


\section{CONCLUSIONS}

The comparative analys is conducted in this report was essentially of two parts. The first analysis was based upon bulk properties (density) and waste loading. From these data the waste form volume and weight required for a spent fuel processing rate of 5MTU/day was calculated. The 100\% PW-9 waste forms required the least volume and total weight of $83 \mathrm{~L} /$ day and $294 \mathrm{~kg} /$ day, respectively. The cement waste forms having a low density and waste loading require the highest volume and weight, averaging $2400 \mathrm{~L} /$ day and $4400 \mathrm{~kg} / \mathrm{day}$, respectively. The other waste forms ranged from 260 to $470 \mathrm{~L} /$ day and 590 to $1500 \mathrm{~kg} /$ day. Product volume and weight become important parameters when considering canister and material cost, or repository capacity.

The second comparative analys is takes into account product durability through the use of mechanical strength, volatility and leach resistance tests. These tests also provide data which is useful in waste form risk analysis. Glass, glass-ceramic, and supercalcine waste forms ranked high in waste form risk analysis. Glass, glass-ceramic, and supercalcine waste forms ranked high in waste form durability. The test results for these forms were very similar as summarized in Table 13 . The $100 \%$ PW-9 calcine waste forms ranked lowest in durability. Additions of cement or glass frit to PW-9 calcine offered some improvement in durability.

Following are some general conclusions that can be made from the contents of this report:

- Glass 76-68, celsian glass-ceramic, and SPC-5B supercalcine rank highest in waste form durability.

- The $100 \%$ PW-9 waste forms require the least volume and weight per unit of processed spent fuel.

- Hot pressing and hot isostatic pressing do not seem to offer significant advantages to cold processing and sintering in terms of leach resistance. 
- Waste matrix interactions in the cement based waste forms may lead to undesirable partitioning of fission products among primary cementous phases.

- The durability of PW-9 calcine is improved by the addition of $50 \%$ glass frit.

TABLE 13. Comparison of Glass, Glass Ceramic, and Supercalcine Waste Forms

$\frac{\text { Property }}{\text { Compress ive Strength, psi }} \quad \frac{\text { Glass } 76-68}{7465 \pm 1945} \quad \frac{\begin{array}{c}\text { Celsian } \\ \text { Glass } \\ \text { Ceramic }\end{array}}{4969 \pm 1206} \quad \frac{\begin{array}{c}\text { Supercalcine } \\ \text { SPC-5B }\end{array}}{4155 \pm 893}$

Volatility, $\mathrm{mg} / \mathrm{mm}^{2}$

$3 \mathrm{hr}$ o $700^{\circ} \mathrm{C}$

$5.0 \times 10^{-4} \quad 2.9 \times 10^{-4}$

$1.5 \times 10^{-4}$

$3 \mathrm{hr}$ o $900^{\circ} \mathrm{C}$

$4.0 \times 10^{-3}$

$1.2 \times 10^{-3}$

$3.0 \times 10^{-4}$

$3 \mathrm{hr}$ o $1100^{\circ} \mathrm{C}$

$2.8 \times 10^{-2}$

$8.8 \times 10^{-2}$

$1.3 \times 10^{-2}$

$3 \mathrm{hr}$ o $1300^{\circ} \mathrm{C}$

$4.1 \times 10^{-1}$

$6.2 \times 10^{-1}$

$2.6 \times 10^{-2}$

Leachability ${ }^{(b)}, \mathrm{g} / \mathrm{m}^{2}$

$\mathrm{Ca}$

Al

B

$\mathrm{Na}$

Mo

$\mathrm{Si}$

Sr

CS

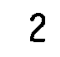

$-$

21

23

19

15

0.5

17.8
2

11

22

13

75

70

20

1

2

(a) Cold pressed and sintered at $1125^{\circ} \mathrm{C}-2 \mathrm{hr}$

(b) Deionized water, $90^{\circ} \mathrm{C}, 3$ days, $S A / S V=6 \mathrm{~m}^{-1}$, normalized units 


\section{ACKNOWLEDGMENT}

In a study as large in scope as this one, many individuals have provided valuable input, not only in technical assistance but also in review and discussion. In the area of materials fabrication, R. H. Wheeler and G. D. Maupin provided much needed assistance. L. R. Bunnell lent valuable guidance in the area of mechanical testing, while W. J. Gray and F. D. Hobbs provided similar expertise in the area of volatility evaluations. G. L. McVay added technical input to much of the leaching work with K. R. Welsch, R. P. Smith, R. E. Woodley and C. R. Buchanan assisting in the conduct of the leach tests themselves. Finally, R. P. Turcotte helped define the initial scope of this study and provided helpful comments on the final report.

Without the combined efforts of all those involved, this study might not have progressed as smoothly and timely as it did. 


\section{REFERENCES}

Bradley, D. J., C. 0. Harvey and R. P. Turcotte. 1979. Leaching of Actinides and Technicium From Simulated High Level Waste Glass. PNL-3152. Pacific Northwest Laboratory, Richland, Washington.

Bunne11, L. R. 1979. Tests for Determining Impact Resistance and Strength of Glass Used For Nuclear Waste Disposal. PNL-2954. Pacific Northwest Laboratory, Richland, Washington.

DuPont DeNemours, E.I. \& Co. 1975. Strategy of Experimentation. E.I. DuPont deNemours \& Co., Wilmington, Delaware.

Gray, W. J. 1976. Volatility of a Zinc Borosilicate Glass Containing Simulated High-Level Radioactive Waste. BNWL-2111, Pacific Northwest Laboratory, Richland, Washington.

Johnson, E. R. and Associates Inc. 1980. Preliminary Evaluation of Alternative Waste Form Solidifcation Processes, Vol. II: Evaluation of the Processes. PNL-3477. Pacific Northwest Laboratory, Richland, Washington.

Lutze, W., J. Borchardt and A. D. De. 1979. "Characterization of Glass and Glass Ceramic Nuclear Waste Forms." Scient if ic Basis for Nuclear Waste Management. G. J. McCarthy, ed. Plenum Press, New York, New York.

Marion, R. H. and J. K. Johnston. 1975. A Parametric Study of the Diametral Compression Test for Ceramics. SAND-75-0347. Sandia Laboratories, Albuquerque, New Mexico.

McElroy, J. L., J. E. Mende 1, W. F. Bonner, and M. H. Henry. 1979. Quarterly Progress Reports Research and Development Activities--High Level Waste Immobilization Program: January through December 1978. PNL-2999-1,2,3,4. Pac ific Northwest Laboratory, Richland, Washington

Ross, W. A., et a1. 1978. Annual Report on the Characterization of High Level Waste Glasses. PNL-2625. Pacific Northwest Laboratory, Richland, Washington.

Rudnick, A., A. R. Hunter and F. C. Holden. 1963. "An Analysis of the Diametral Compression Test." Mat. Res. \& Stds., 3:283-288.

Rusin, J. M. 1978. Applicability of Alternative Waste Forms for Immobilization of Alternative Fuel Cycle Wastes. PNL-2775. Pacific Northwest Laboratory, Richland, Washington.

Smith, T. H. and W. A. Ross. 1975. Impact Testing of Viterous Simulated High Level Waste in Cannisters. BNWL-1903. Pacific Northwest Laboratory, Richland, Washington. 
Spriggs, R. M., L. A. Brissette and T. Vosilos. 1964. "Tensile Strength of Dense Polycrystalline Ceramics by the Diametral Compression Test." Mat. Res. \& Stds., $\underline{3}: 283-288$.

Treat, R. L. 1980. "A Comparative Study of Alternative High-Level Waste Solidification Processes." Proc. Symp. Waste Mgmt., Tucson, Arizona. 



\section{DISTRIBUTION}

No. of

Copies

\section{OFFSITE}

UNITED STATES
A. A. Churm
DOE Chicago Patent Group
9800 South Cass Avenue
Argonne, IL 09439
R. E. Cunningham
Deputy Director, Div. of Fuel
Cycle and Materials
Office of Nuclear Safety
Materials and Safeguards
Room 562
Nuclear Regulatory Commission
7915 Eastern Avenue
Silver Springs, MD 20910
J. B. Martin
Assistant Director for
Radioactive Waste
Management Branch
NRC Division of Materials and
Fuel Cycle Facility Licensing
Washington, DC 20555
R. B. Chitwood
DOE Division of Nuclear
Power Development
Washington, DC 20545
T. C. Chee
DOE Office of Nuclear Waste
Management
Washington, DC 20545

No. of

Copies

D. M. Rohrer

High-level Wast Technical Development Branch

Nuclear Regulatory Commission

Washington, DC 20545

W. G. Belter

DOE Division of Biomedical and Environmental Research

Earth Sciences Branch

Washington, DC 20545

W. A. Brobst

DOE Division of Environmental Control Technology

Washington, DC 20545

W. E. Mott

DOE Division of Environmental Control Technology

Washington, DC 20545

C. R. Cooley

DOE Office of Nuclear Waste Management

Washington, DC 20545

C. H. George

DOE Office of Nuclear Waste Management

Washington, DC 20545

C. A. Heath

DOE Office of Nuclear Waste Management

Washington, DC 20545 
No. of

Copies

G. Derte1

DOE Office of Nuclear Waste Management

Washington, DC 20545

Sheldon Meyers

DOE Office of Nuclear Waste Management

Washington, DC 20545

R. G. Romatowski

DOE Office of Nuclear Waste Management

Washington, DC 20545

A. F. Perge

DOE Office of Nuclear Waste

Management

Washington, DC 20545

D. L. Vieth

DOE Office of Nuclear Waste Management

Washington, DC 20545

R. D. Walt ton

DOE Office of Nuclear Waste Management

Washington, DC 20545

A. L. Taboas

TRU Waste Management Program

DOE Albuquerque Operations

Office

P.0. Box 5400

Albuquerque, NM 87185

J. Neff, Program Manager

Department of Energy

Columbus Program Office

$505 \mathrm{King}$ Avenue

Columbus, $\mathrm{OH} 43201$

J. B. Whitsett

DOE I daho Operations Office

P.0. Box 2108

Idaho Falls, ID 83401
No. of

Copies

John Van Cleve

DOE Oak Ridge Operations Office

P.0. Box $X$

Oak Ridge, TN 37830

E. S. Goldberg

DOE Savannah River Operations Office

P.0. Box A

Aiken, SC 29801

27 DOE Technical Information Center

A. P. Roeh, Manager

Exxon Nuclear

Idaho Corporation

P.0. Box 2800

Idaho Falls, ID 83401

Exxon Nuclear Idaho

(File Copy)

P.0. Box 2800

Idaho Falls, ID 83401

J. R. Berreth

Exxon Nuclear

Idaho Corporation

P.0. Box 2800

Idaho Falls, ID 83401

R. A. Brown

Exxon Nuclear

Idaho Corporation

P.0. Box 2800

Idaho Falls, ID 83401

C. A. Hawley

Exxon Nuclear

Idaho Corporation

P.0. Box 2800

Idaho Falls, ID 83401

D. A. Knecht

Exxon Nuclear

Idaho Corporation

P.0. Box 2800

Idaho Falls, ID 83401 
M. D. McCormack

E.G. G. Idaho, Inc.

P.0. Box 1625

Idaho Falls, ID 83401

W. C. Seymour

E.G. \& G. Idaho, Inc.

P.0. Box 1625

Idaho Falls, ID 83401

J. A. Buckham

Allied-General Nuclear Services

P.0. Box 847

Barnwe11, SC 29812

A. Williams

Allied-General Nuclear Services

P.0. Box 847

Barnwe11, SC 29812

J. L. Cranda11

E. I. duPont deNemours \& Company

Savannah River Laboratory

Aiken, SC 29801

J. L. Jardine

Argonne National Laboratory 9700 South Cass Avenue

Argonne, IL 60439

M. J. Steindler/L. E. Trevorrow Argonne National Laboratory 9700 South Cass Avenue Argonne, IL 60439

Battelle Memorial Institute

Office of Nuclear Waste Isolation

Attn: Ms. Beverly Rawles

505 King Avenue

Columbus, $\mathrm{OH} 43201$

N. E. Carter

Office of Nuclear Waste Isolation

Battelle Memorial Institute

$505 \mathrm{King}$ Avenue

Columbus, $\mathrm{OH} 43201$
M. Kehnemuyi

Office of Nuclear Waste Isolation

Battelle Memorial Institute 505 King Avenue

Columbus, $\mathrm{OH} 43201$

P. L. Hofmann

Office of Nuclear Waste Isolation

Battelle Memorial Institute $505 \mathrm{King}$ Avenue

Columbus, $\mathrm{OH} 43201$

J. M. Batch

Battelle Memorial Institute $505 \mathrm{King}$ Avenue

Columbus, $\mathrm{OH} 43201$

Wayne Carbiener

Battelle Memorial Institute

505 King Avenue

Columbus, $\mathrm{OH} 43201$

J. D. Duguid

Battelle Memorial Institute $505 \mathrm{King}$ Avenue

Columbus, $\mathrm{OH} 43201$

R. E. Heineman

Battelle Memorial Institute $505 \mathrm{King}$ Avenue

Columbus, $\mathrm{OH} 43201$

J. Kircher

Office of Nuclear Waste Isolation

Battelle Memorial Institute

$505 \mathrm{King}$ Avenue

Columbus, $\mathrm{OH} 43201$

Don Moak

Battelle Memorial Institute

$505 \mathrm{King}$ Avenue

Columbus, $\mathrm{OH} 43201$ 
No. of

Copies

Ken Yates

Battelle Memorial Institute

505 King Avenue

Columbus, $\mathrm{OH} 43201$

2 Brookhaven National Laboratory

Reference Section

Inf ormation Division

Upton, Long IsI and, NY 11973

Combustion Division

Combusion Engineerings, Inc.

Windsor, CT 06095

Lawrence J. Smith

TRU Waste Systems Office

Bldg. T-790

Rockwe 11 International

Rocky Flats Plant

P.0. Box 464

Golden, C0 80401

E. Vejvoda, Director

Chemical Operations

Rockwell International

Rocky Flats Plant

P.0. Box 464

Golden, CO 80401

Research Library

Battelle Memorial Institute

505 King Avenue

Columbus, $\mathrm{OH} 43201$

7 C. D. Zerby

Union Carbide Corporation

Nuclear Division

Office of Waste Isolation

P.0. Box Y

Oak Ridge, TN 37830

J. L. Crandall

E. I. duPont deNemours \& Company

Savannah River Laboratory

Aiken, SC 29801
No. of

Copies

Jim Howel

E. I. duPont deNemours \& Company Savannah River Laboratory

Aiken, SC 29801

H. L. Hull

E. I. duPont deNemours \& Company Savannah River Laboratory

Aiken, SC 29801

R. G. Garvin

E. I. duPont deNemours \& Company Savannah River Laboratory

Aiken, SC 29801

D. L. McIntosh

E. I. duPont deNemours \& Company Savannah River Laboratory

Aiken, SC 29801

J. A. Kelley

E. I. duPont deNemours \& Company Savannah River Laboratory

Aiken, SC 29801

Robert Maher

E. I. duPont deNemours \& Company Savannah River Laboratory

Aiken, SC 29801

J. K. Okeson

E. I. duPont deNemours \& Company Savannah River Laboratory

Aiken, SC 29801

M. S. Plodinec

E. I. duPont deNemours \& Company Savannah River Laboratory

Aiken, SC 29801

Leon Meyers

E. I. duPont deNemours \& Company Savannah River Laboratory Aiken, SC 29801 
No. of

Copies

M. D. Boersma

E. I. duPont deNemours \& Company Savannah River Laboratory

Aiken, SC 29801

A. S. Jennings

E. I. duPont deNemours \& Company Savannah River Laboratory

Aiken, SC 29801

S. Mirschak

E. I. duPont deNemours \& Company Savannah River Laboratory

Aiken, SC 29801

P. H. Permar

E. I. duPont deNemours \& Company Savannah River Laboratory

Aiken, SC 29801

R. F. Williams

Electric Power Research Institute

3412 Hillview Avenue

P.0. Box 10412

Palo Alto, CA 94304

Environmental Protection Agency

Technology Assessment Division (AW-559)

Office of Radiation Programs

U.S. Environmental Protection Agency

Washington, DC 20460

R. G. Barnes

General Electric Company

175 Curtner Avenue

(M/C 160)

San Jose, CA 95125

L. H. Brooks

Gulf Energy and Environmental Systems

P.0. Box 81608

San Diego, CA 92138
No. of

Copies

2 Central Research Library

Document Reference Section

Oak Ridge National Laboratory (DOE)

Oak Ridge, TN 37830

3 Los Alamos Scientific Laboratory P.0. Box 1663

Los Alamos, NM 87544

D. C. Fulmer

Savannah River Operations Office P.0. Box A

Aiken, SC 29801

C. J. Kershner

Mons anto Research Corporation

Mount Laboratory

P.0. Box 32

Miamiburg, OH 45342

J. G. Cline, General Manager NYS Atomic and Space Development Authority

230 Park Avenue, Rm. 2425

New York, NY 10017

John Pomeroy

Technical Secretary

National Acameny of Sciences

Committee of Radioactive Waste

Management

National Research Council

2101 Contitution Avenue

Washingtin, DC 20418

2 M. A. Thompson

Rockwell International

Rocky Flats Division

Golden, CO 80401

L. Henning

Electric Power Research Institute

3412 Hillview Avenue

P.0. Box 10412

Palo Alto, CA 94304 
No. of

Copies

E. H. Kobisk

Solid State Division

Oak Ridge National Laboratory

Oak Ridge, TN 37830

G. J. McCarthy

Department of Chemistry

North Dakota State University

Fargo, ND 58102

Rod Ewing

University of New Mexico

Albuquerque, NM 87131

2 J. P. Duckworth

Plant Manager

Nuclear Fuels Services, Inc.

P.0. Box 124

West Valley, NY 14171

J. L. Larocca, Chairman

Engineering Research and

Development Authority

Empire State Plaza

Albany, NY 12223

D. R. Anderson

Sandi a Laboratories

Albuquerque, NM 87185

W. Weart

Division 1140

Sandia Laboratories

Albuquerque, NM 87185

J. Sivinski

Sandia Laboratories

A1buquerque, NM 87185

0 . E. Jones

Sandia Laboratories

Albuquerque, NM 87185

J. W. Bartlett

The Analytical Sciences Corp.

6 Jacob Way

Reading, MA 01867
No. of

Copies

R. E. Blanco

Union Carbide Corporation (ORNL)

Chemical Technology Division

P.0. Box $Y$

Oak Ridge, TN 37830

E. Newman

Union Carbide Corporation (ORNL)

Chemical Technology Division

P.0. Box $Y$

Oak Ridge, TN 37830

A. L. Lotts

Union Carbide Corporation (ORNL)

Chemical Technology Division

P.0. Box $Y$

Oak Ridge, TN 37830

W. J. Lackey

Union Carbide Corporation (ORNL)

Chemical Technology Division

P.0. Box $Y$

Oak Ridge, TN 37830

T. Lindemer

Union Carbide Corporation (ORNL)

Chemical Technology Division

P.0. Box $Y$

Oak Ridge, TN 37830

H. W. Godbee

Union Carbide Corporation (ORNL)

Chemical Technology Division

P.0. Box $Y$

Oak Ridge, TN 37830

W. C. McClain

Union Carbide Corporation (ORNL)

Chemical Technology Division

P.0. Box $Y$

Oak Ridge, TN 37830

J. 0. Blomeke

Union Carbide Corporation (ORNL)

Chemical Technology Division

P.0. Box $Y$

Oak Ridge, TN 37830 
No. of

Copies

D. E. Ferguson

Union Carbi de Corporation (ORNL)

Chemical Technology Division

P.0. Box Y

Oak Ridge, TN 37830

R. A. Beall

U.S. Department of Interior Bureau of Mines

Albany Research Center

1450 W. Queen Avenue

Albany, OR 87321

R. G. Post

College of Engineering

University of Arizona

Tucson, AZ 85721

J. K. Johnstone

Sandi a Laboratories

Albuquerque, NM 87107

S. E. Logan

University of New Mexico

Albuquerque, NM 87131

Stewart Farber

New Engl and Power Company

$280 \mathrm{Mel}$ rose Street

Providence, RI 02901

D. B. Stewart

U.S. Department of Interior

959 National Center

Geological Survey

Reston, VA 22092

Professor Guna Salvaduray

Materials Engineering

San Jose State University

San Jose, CA 95192

B. Adams

Corning Glass Works

Technical Staffs Division

Corning, NY 14830
No. of

Copies

ONSITE

8 DOE Richland Operations Office

E. A. Bracken

P. A. Craig

R. D. Gerton

H. E. Ransom

J. J. Schreiber

M. W. Shupe

M. J. Zamorski

0. J. Elgert

13 Rockwell Hanford Operations

H. Babad

L. C. Brown

R. A. Deju

R. J. Gimera

D. R. Gustavson

E. J. Kosiancic

M. J. Kupfer

C. M. Manry

J. H. Roecker

W. W. Schulz

M. J. Smith

D. D. Wodrich

File Copy

Exxon

Richland, WA 99352

S. J. Beard

2 Joint Center for Graduate Study

J. Cooper

L. C. Olsen

2 UNC United Nuclear Industries

T. E. Dabrowski

A. E. Engler

Westinghouse Hanf ord Company

A. G. Blasewitz 

No. of

Copies

97 Pacific Northwest Laboratory

S. M. Barnes

W. J. Bjorklund

H. T. Blair

W. F. Bonner

D. J. Bradley

D. W. Brite

J. L. Buelt

L. R. Bunnell

J. G. Carter

L. A. Chick

T. D. Chikalla

J. G. Exarhos

W. J. Gray

W. E. Gurwell

A. J. Haverfield

O. F. Hill

L. K. Holton

E. R. Irish

J. H. Jarrett

Y. B. Katayama

R. S. Kemper

D. E. Knowlton

D. E. Larson

R. 0. Kokken

R. P. Marshall

J. L. McEl roy
No. of

Copies

G. L. McVay

G. B. Mellinger

J. E. Mendel

R. D. Nel son

J. F. Nesbitt

R. E. Nightingale

C. R. Palmer

A. M. Platt

D. L. Prezbindowski

R. D. Roberts

W. A. Ross

J. M. Rusin (30)

J. W. Shade

D. H. Siemens

S. C. Slate

D. M. Strachan

C. L. Timmerman

R. L. Treat

R. P. Turcotte (2)

H. H. Van Tuyl

J. W. Voss

J. W. Wald (5)

W. J. Weber

R. E. Westerman

J. H. Westsik, Jr.

L. D. Williams

W. K. Winegardner

Technical Inf ormation (5)

Publishing Coordination $\mathrm{GO}(2)$ 
: 